\title{
THE CONTEMPORARY FUNCTION OF THE CLASS SUIT
}

\author{
Harry Kalven, JR., and Maurice Rosenfteld* \\ No man is an Iland, intire of it selfe; every man is a peece \\ of the Continent, a part of the maine. .... \\ -John Donne
}

HE WIDE diffusion of securities has created a situation where
the single and isolated security holder usually is helpless in pro-
tecting his own interests or pleading his own cause," reported the Securities and Exchange Commission in I937. "The plight of the individual investor," the commission added, "is accentuated where he is uninformed and unskilled in the intricacies of finance. It is likewise accentuated where his investment is so small that it becomes either impossible or improvident for him to expend the funds necessary to prosecute his claims or defend his position."

Although the commission's comment was made with immediate reference only to the individual investor in corporate reorganization cases, it applies equally well to many other situations today. The employee who is entitled to time and a half for overtime, the stockholder who has been misled by a false statement in a prospectus, the rate-payer who has been charged an excessive rate, the depositor in a closed bank, the taxpayer who resists an illegal assessment, or the small business man who has been the victim of a monopoly in restraint of trade, like the investor in the reorganization, finds himself inadvertently holding a small stake in a large controversy. The type of injury which tends to affect simultaneously the interest of many people is also apt to involve immensely complex facts and intricate law, and redress for it is likely to involve expense totally disproportionate to any of the individual claims.

Consider, for example, the plight of those who bought into the $\$ 60,-$ $\infty, 0 \infty$ debenture issue of Insull Utilities Investments, the top holding

* Members of the Illinois Bar.

I Report on the Study and Investigation of the Work, Activities, Personnel and Functions of Protective and Reorganization Committees, Part II, at I (1937). This report (in eight parts) will be cited hereafter as SEC Report.

${ }^{2}$ Cf. remarks of Commissioner Prouty in Cattle Raisers' Ass'n of Texas v. Chicago, B. \& Q. R. Co., Io I.C.C. 83, 95 (1904); Craig, J., dissenting in Golden v. Cervenka, 278 Ill. 409, 446, 452 , II6 N.E. $273,288,290$ (I917). 
company in the Insull hierarchy. When the system collapsed and the individual holder discovered he was not to be paid, he was faced with the almost insuperable problem of ascertaining whether he had any basis for redress. He was required somehow to appraise the possibilities that some of the vast number of financial transactions involved mismanagement by the directors, or that there were abuses in the incredible complexity of the intercompany structure, or that perhaps the celebrated and esoteric "negative pledge" clause had been violated. To have had any sort of knowledge or opinion on these points would have required literally months of intensive investigation and sophisticated research. To put it bluntly, the picture had become so complex that the individual could not know whether he had been "robbed" or not.

Moreover, almost no single investor's stake would warrant the enormous expense of his seeking legal redress. The investor who held, say, $\$ 10,000$ in debentures, was confronted with expenses measured by a $\$ 60$,$\infty, \infty \infty$ lawsuit, not a $\$ 10, \infty \infty$ one. $^{3}$ Clearly, if any redress was to be sought, it was imperative that it be sought on behalf of and be paid for by the debenture holders as a group, and the actual career of the case corroborates this statement. 4 The Insull case is, of course, extreme, and some of its evils have already been corrected by substantive law reforms. Nevertheless it serves to highlight the twin factors of ignorance and expense which are present in virtually all cases of large-scale group injuries. ${ }^{5}$

${ }^{3} \mathrm{Mr}$. Justice Douglas has made this point with perhaps a bit more gusto: "In the first place, it took no great understanding of the mysteries of high finance to make obvious the futility of spending a thousand dollars to get a thousand dollars-or even less." Douglas, Protective Committees in Railroad Reorganizations, 47 Harv. L. Rev. 565, 567 (I934).

4 The two attempts to obtain redress in this case both involve group action. The first was a class suit against certain banks which received collateral, allegedly in violation of the "negative pledge" clause. Kelly v. Central Hanover Bank \& Trust Co., Ir F. Supp. 497 (N.Y. I935), remanded for further findings of fact, 85 F. (2d) 61 (C.C.A. $2 \mathrm{~d}$ 1936). While this latter proceeding was pending the case was settled for approximately $\$ 3,500,000$ and the withdrawal by the banks of claims of $\$ 72, \infty 0, \infty \infty$ against the bankrupt estate. A second suit, a class suit against the company's directors for mismanagement, declaration of illegal dividends, and inducing violation by the corporation of the negative pledge clause, is still pending. Aiken v. Insull, No. 7430 in the Circuit Court of Appeals for the Seventh Circuit.

Two other points about the history of the case are worth noting: (I) a substantial fraction of the investigatory work was done by a government staff pursuant to the unsuccessful criminal prosecution of Mr. Insull; (2) the fees and expenses of approximately a half-million dollars awarded in the proceedings indicate the expense of seeking redress in this type of case.

$3 \mathrm{~A}$ somewhat different facet of the problem is presented by the employee cases under the Fair Labor Standards Act of 1938, 52 Stat. 1060 (1938), 29 U.S.C.A. \& 201 (Supp. 1940). There the case may well be relatively simple and the expenses involved not excessive, but the claim of the individual employee is likely to be much smaller than in the investor cases; and equally important, the employees are in an income group which as a rule does not employ lawyers in 
Modern society seems increasingly to expose men to such group injuries for which individually they are in a poor position to seek legal redress, either because they do not know enough or because such redress is disproportionately expensive. If each is left to assert his rights alone if and when he can, there will at best be a random and fragmentary enforcement, if there is any at all. This result is not only unfortunate in the particular case, but it will operate seriously to impair the deterrent effect of the sanctions which underlie much contemporary law. The problem of fashioning an effective and inclusive group remedy is thus a major one.

One important answer is afforded by the contemporary development of administrative law. President Roosevelt, in his veto message on the Logan-Walter Bill, ${ }^{6}$ described the plight of the individual who has a small share in a large controversy and commended strongly the use of administrative bodies as the remedy: "Individual shippers could not cope in the courts with great railroad corporations over excessive charges that were small in single cases but important in the aggregate. So the Interstate Commerce Commission was created. Power consumers could not deal with electric rates, nor could individual security holders pit their strength against the concentrated power of brokerage interests, nor could individual laborers bargain on equality with the concentrated power of employers. The very heart of modern reform administration is the administrative tribunal. A 'truth in securities' act without an administrative tribunal to enforce it or a labor-relations act without an administrative tribunal to administer it, or rate regulation without a commission to supervise rates would be sterile and useless." 7

Administrative law removes the obstacles of insufficient funds and insufficient knowledge by shifting the responsibility for protecting the interests of the individuals comprising the group to a public body which has ample funds and adequate powers of investigation. Primarily, it is a method of preventing injuries by the injunction, the stop order, and the cease and desist order; by pre-licensing and revocation; by establishing a

individual cases. Here again, unless there is economy of redress for the group as a unit, there is apt to be no redress for anyone.

Finally, there are the rate-payer cases. For example, in the well-known Illinois Bell Telephone Company rate case, the claims of the individual consumers were in most instances so small as not to warrant any individual litigation. Protracted litigation, however, did result in the actual distribution to subscribers of about $\$ 17, \infty, \infty, \infty$. It was estimated that 85 per cent of the claims were under $\$ 25$ and that refunds were made to more than a million claimants. The final phase of the litigation is reported in Illinois Bell Tel. Co. v. Slattery, roz F. (2d) 58 (C.C.A. $7^{\text {th }}$ 1939).

${ }^{6}$ H.R. 6324,76 th Cong. 3 d Sess. (1940). 786 Cong. Rec. 21501 (1940). 
rate for the future; or by outlining a very detailed pattern for future conduct. But it is important to note that an administrative body does not normally act to remedy wrongs which have occurred. ${ }^{8}$ It is true that in recent years there have been some suggestive instances where an administrative body has taken affirmative action and in effect brought civil litigation on behalf of the group after the injury occurred. An example is afforded by the Wage and Hour Division's obtaining restitution of back wages for employees. 9 Important, too, is the activity of the SEC as a participant in reorganization proceedings, where it functions very much like a private investor or a committee for private investors..$^{\text {to }}$

This power of administrative bodies, to act affirmatively after the injury, is still in the tentative stage, and there are, of course, many fields in which administrative bodies have not made an appearance. As a consequence, whether it is desirable or not, private litigation must still police large areas of modern law and provide the exclusive remedy for many largescale group injuries. It is the primary concern of this article to explore the possibilities of revitalizing private litigation to fashion an effective means of group redress.

Off-hand it might seem that a satisfactory solution to the problem is afforded by the simple expedient of multiple joinder under modern rules of procedure. Undeniably, excellent reforms have been made in recent years, and joinder statutes are almost everywhere exceedingly liberal..$^{\mathrm{rr}}$ Undeniably too, joinder has on occasion served as a completely satisfactory vehicle for group redress. Thus, in a leading New York case, nearly two hundred investors who were the victims of fraud were able to obtain relief in a single action, ${ }^{12}$ and similar cases are readily found. The cardinal difficulty with joinder, however, is that it presupposes the prospective plaintiffs' advancing en masse on the courts. In most situations

${ }^{8}$ III-B Sharfman, The Interstate Commerce Commission 329 (1936). Attempts by commissions to rectify past abuses for an entire consumer group by compelling a utility to undercharge in the future are interesting in this connection. Board of Public Utility Com'ns v. New York Tel. Co., 27 I U.S. 23 (I926) (revised rate held confiscatory).

9 The Wage and Hour Division does not have the power to sue directly for back wages on behalf of employees, but through consent decrees and public relations it has obtained restitution in a substantial number of cases. E.g., Fleming v. North Georgia Mfg. Co., 33 F. Supp. I005 (Ga. I940). The division reported in I940 that it had obtained the restitution of over $\$ 5, \infty 00,000$ in back wages to employees. Wage and Hour Rel. No. R-1273, at 2 (194I).

ro Teton, Reorganization Revised, 48 Yale L. J. 573, 583 (1939).

II Judicial construction of the key phrase "the same transaction or series of transactions" has, however, on occasion unfortunately limited the scope of the code provisions. Gombi v. Taylor Washing Machine Co., 290 III. App. 53, 7 N.E. (2d) 929 (1937).

${ }^{22}$ Akely v. Kinnicutt, 238 N.Y. 466 , x44 N.E. 682 (1924). 
such spontaneity cannot arise because the various parties who have the common interest are isolated, scattered, and utter strangers to each other. Thus while the necessity for group action through joinder clearly exists, the conditions for it do not. It may not be enough for society simply to set up courts and wait for litigants to bring their complaints-they may never come.

What is needed, then, is something over and above the possibility of joinder. There must be some affirmative technique for bringing everyone into the case and for making recovery available to all. It is not so much a matter of permitting joinder as of ensuring it. There are basically two methods for doing this. The first is to organize the various claimants prior to suit and make them all parties plaintiff to the litigation; this is the committee technique. The second is to ignore the various claimants until a decree has been obtained and then to hold open the decree and to permit them upon solicitation under court auspices to participate in the benefits of the decree. The suit in form will be brought initially by any member of the group who, unchosen and unasked and without soliciting consents from the others or organizing them prior to trial, volunteers to assert the rights of all. This is the technique of the class suit.

Preliminary to an exploration of the utility of the class suit as an instrument for effective and inclusive group redress, it will be useful to take up briefly the institution of the committee as the alternative device.

\section{I}

It is undoubtedly true that if everyone injured were made a party plaintiff before trial an effective and inclusive group remedy would then be available. Expenses and knowledge would be shared, and the total claim of all would warrant vigorous investigation and prosecution. Finally, if the case were won all would be entitled to share in the recovery. As has already been suggested, however, the group will not voluntarily and spontaneously join in the action because of their dispersion and anonymity. If there is to be large-scale participation before trial, it is necessary that there be an aggressive, determined organization-drive, necessitating the use of something akin to the reorganization committee. ${ }^{13}$

${ }^{3}$ The analogy between the committee and the association has sometimes been made quite explicit. Carriers' Protective Committee v. Bornstein, I8 P.U.R. (N.s.) 527 (Pa. I937). The "association" may have been organized solely to facilitate the bringing of particular litigation, or it may be semi-permanent and take on other functions. Taxpayers' associations are, of course, well known, and associations of shippers have long prosecuted claims before the ICC. Independent Refiners Ass'n v. Western N.Y. \& P.R. Co., 4 I.C.C. I62 (I892); Cattle Raisers' Ass'n of Texas v. Chicago, B. \& Q. R. Co., xo I.C.C. 83 (Igo4).

Two interesting cases have arisen since the Federal Rules of Civil Procedure have gone into 
The utility of this device is subject to some serious reservations. In the first place the committee is in considerable disrepute at the moment; the tremendous volume of experience with reorganization committees during the depression years was disillusioning. ${ }^{x_{4}}$ Even those who believe that the committee could serve a useful function have advocated stringent controls over it. ${ }^{15}$ More serious is the fact that recent reforms in the reorganization field have tended in the direction of drastically subordinating the committee or eliminating it altogether, by delegating its functions to the bankruptcy trustee, ${ }^{16}$ to the indenture trustee, ${ }^{17}$ and to the SEC. In brief, in the one type of case in which the committee has been used extensively it has been tried and found wanting.

Clearly, some of the abuses to which reorganization committees were subject are peculiar to reorganizations, such as affiliation of committee members with the banker and management groups and the disposition of what the SEC likes to call "the emoluments of control." On the other hand, some of the difficulties are perhaps aggravated when the committee technique is used outside of reorganizations. There is the real possibility that oppressive powers of attorney and excessive fee contracts will be solicited, comparable to the worst of the reorganization deposit agreements. And in most instances there would not even be the limited control that was exercised under the earlier reorganization procedures. ${ }^{18}$ Fur-

effect. Nat'l Hairdressers' \& Cosmetologists' Ass'n, Inc. v. Philad Co., 34 F. Supp. 264 (Del. I940); Alabama Independent Service Station Ass'n, Inc. v. Shell Petroleum Corp., 28 F. Supp. 386 (Ala. 1939). In each case the association was held technically defective as a party plaintiff, but the suit was permitted to continue as a class suit. It might be noted, too, that labor unions are frequently instrumental in wage and hour suits. Fishman v. Marcouse, 32 F. Supp. 460 ( $\mathrm{Pa}$. I940); Lengel v. Newark Newsdealers Supply Co., 32 F. Supp. 567 (N.J. I940).

Finally, an organization such as ASCAP is of interest. Originally, its primary purpose was to use group resources to facilitate investigation and prosecution of copyright infringements. It has since become a channel for marketing artistic products and services. See Rosenberg and Cohn, State Regulation of Musical Copyright, 33 Ill. L. Rev. 548 (x939).

${ }_{14}$ The most exhaustive treatment is contained in SEC Reports, Parts I-VIII (1936-40).

15 Douglas, Protective Committees in Railroad Reorganizations, 47 Harv. L. Rev. 565 (1934); SEC Report, Part I, at 903-907 (I936); ibid., Part II, at 528-34 (1937). The commission's recommendations were embodied in the Lea Bill, H.R. 6968, 75th Cong. Ist Sess. (I937), which remains the one major piece of reform legislation proposed by the commission but not enacted by Congress.

${ }^{26}$ In cases over $\$ 250, \infty 00$, provision is made by $\$ \$ 167-69$ of the Chandler Act for the appointment of a disinterested trustee, one of whose primary functions is to formulate the reorganization plan. $5^{2}$ Stat. 888, 890 (I938), II U.S.C.A. $\$ \S 567-69$ (r939).

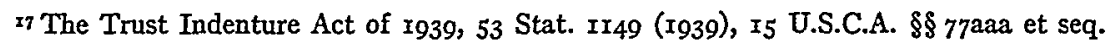
(Supp. r940).

${ }_{28}$ United States v. Chicago, M. \& St. P. R. Co., 282 U.S. $3^{\text {II }}$ (x93I); Levi and Moore, Bankruptcy and Reorganization: A Survey of Changes. II, 5 Univ. Chi. L. Rev. 219, 228 et seq. (1938); SEC Report, Part VIII, at 204 et seq. (I940). 
ther, the manner of soliciting would readily lend itself to abuse with nondisclosure, misrepresentation, and in general the unpleasantness of a vigorous campaign of high pressure salesmanship. ${ }^{\text {9 }}$

Again, the committee method used apart from reorganizations may well give rise to new difficulties. For example, broadcast solicitation prior to any determination of the controversy on its merits may frequently expose an innocent defendant to unnecessary and unfortunate adverse publicity. Thus, the solicitation of powers in an investor fraud action under the Securities Act of 1933 , despite the possible supervision of the commission over the soliciting material, ${ }^{20}$ could prove materially damaging to the management, stir up investors prematurely, and confuse and upset the market for their securities. Further, the power to use the committee technique is an invitation to the strike-suit minded. The mere threat of sustained, unfavorable publicity, especially where there is no outside regulation, may of itself give a sufficient "nuisance" position for extorting a settlement.

The most serious reservation to the use of the committee in non-reorganization cases is that as a practical matter it is not likely to achieve its purpose. In most instances only a relatively small fraction of the group will respond to the solicitation. It is true that not too many concessions should be made to the apathy and disinterest of people in their own affairs, but, especially in non-financial cases, the committee may seem strange and suspect, the soliciting material too complex, and in general the whole thing may seem better left alone. When the soliciting material is coupled with a request for immediate expense funds, the disinclination of members of the group to respond will, of course, be deepened and understandably so.

In any event the function of a layman committee in these cases is certainly a narrow one. It amounts simply to the organizing or mobilizing of the plaintiffs, and once the suit has begun it virtually ceases. It should be remembered that the principal function which it was argued the committee could fulfil in reorganizations was not merely to organize but to represent and that its representative function arose because, in Mr. Foster's phrase, of the need for "vicarious negotiation."2x There is no comparable

19 See material collected in SEC Report, Part I, at 457-576 (I937). The use of solicitors paid on a contingent fee basis was not infrequent. Ibid., at 478 et seq.

${ }^{20}$ The commission's power is derived from $\S I_{4}(\mathrm{a})$ of the Securities Exchange Act of 1934, 48 Stat. 895 (I934), I5 U.S.C.A. $\$ 78 \mathrm{n}$ (a) (Supp. I940). It is not altogether clear that the soliciting of a mere authorization to sue falls within the section, even though the securities involved are listed on a national exchange, although the result of such a construction is desirable.

${ }^{21}$ Foster, Review of Lowenthal, The Investor Pays, 43 Yale L.J. 352, 357 (I933). 
function for the committee in the conduct of a lawsuit. Even in the event of settlement its decisions will almost inevitably be those of its counsel.

The committee, then, functions only to bring the parties into the suit; this it does only half well at best and under conditions easily tending to serious abuse. If there is another method for bringing the various and scattered parties together to participate in a common recovery, it will almost certainly be preferable to the committee method. Such a method, it is believed, is afforded by the class suit properly understood.

II

The method of the class suit is to permit any member of the group individually, unchosen and unasked and without any organization of the class or prior consent from others, to step forward and sue on behalf of all, in the sense that if he is successful all may participate in his result. The chief difference between this method and the committee method is simply that instead of mobilizing the plaintiffs prior to trial, their participation in the case is deferred until a decision is reached. In lieu of any aggressive solicitation of powers of attorney before trial, there is substituted a simple notice after the decision that relief is available. It is evident that the class suit method preserves and strengthens all the possible advantages of the committee technique. A practical opportunity for recovery is made available to all; expenses and knowledge are shared by all; and the size of the total claim of the class warrants vigorous prosecution of the rights of the class. And these advantages are obtained without the disadvantages of the committee technique. First, there is no occasion for individual fee contracts or powers of attorney-all fees are awarded by the court on a quantum meruit basis. ${ }^{22}$ Second, there is no unfair unleashing of adverse publicity, because prior to solicitation the case has been decided on its merits, and any solicitation is under court auspices. ${ }^{23}$ Finally, the method is likely to be almost completely successful inasmuch as the various members are simply notified that a completed recovery is available for them; they are not asked to put up money or to give authorizations, but are simply asked to "come and get it."

The contrast between the committee approach and the class suit approach may be seen most sharply from an examination of the familiar shareholder's derivative suit. Although serious doubts have been expressed as to its complete efficacy, ${ }^{24}$ there is general agreement that it furnishes the major sanction behind the fiduciary rules of corporation law. Here the theory of recovery has been completely worked out. Any shareholder

${ }^{22}$ See infra, pp. $75^{-16}$.

${ }^{23}$ See infra, pp. 693-94.

24 Note 96 infra. 
may initiate the litigation, and by virtue of the fact that he is treated as derivatively asserting the corporate cause of action, his claim is the total claim of all the shareholders. If he is successful, recovery automatically inures pro rata to the benefit of each member of the class, and counsel fees and expenses are distributed over the entire class. The suit, then, is the perfect method of group redress, accomplished without any of the cumbersome paraphernalia of the committee. The really significant thing is that a single shareholder, without being asked or without procuring the authorization of other shareholders, simply volunteers to present their case as well as his own to the court. It is the best example of effective and inclusive redress through vicarious litigation. ${ }^{25}$

The shareholder's suit has one advantage, it must be admitted, which is not completely available in cases where the cause of action cannot be said to belong to the entity. The corporation, by acting as a receptacle for the cause of action, makes unnecessary any solicitation and affirmative action by the beneficiaries of the plaintiff-shareholder's litigation..$^{26}$ In cases where there is no entity, solicitation and notice after the decree provide the mechanical substitute for the entity as the device for making participation in the recovery available to all. With this one adjustment, the class suit becomes as effective a procedural form for group redress for the employee, ${ }^{27}$ the investor, ${ }^{28}$ the ratepayer, ${ }^{29}$ the taxpayer, ${ }^{30}$ et al. ${ }^{3 \mathrm{x}}$ as the de-

25 Cf. Berle, Compensation of Bankers and Promoters through Stock Profits, 42 Harv. I. Rev. 748, 759 ก. 25 ( $x 929$ ).

${ }^{26}$ There is an infrequent exception where the wrongdoers or those implicated in the wrong are themselves shareholders. In these cases the recovery may run to the innocent shareholders directly and not to the corporation. Brown v. De Young, I67 Ill. 549, 47 N.E. $86_{3}$ (I897). Under these circumstances the derivative suit becomes exactly equivalent to the ordinary class suit. Backus v. Finkelstein, 23 F. (2d) 357 (D.C. Minn. I927) (discussing participation and solicitation).

There is a serious question as to whether the derivative suit effects recovery for those really injured. The use of the derivative suit tends automatically and accidentally to confer the benefits of the suit upon those who hold shares at the date of recovery. Cf. Compensation for Stockholders Actually Injured by Promoters' Frauds, 47 Harv. L. Rev. I03I (I934). The question of whether the old or the new shareholders should be given the recovery is a difficult and important one, but its solution should not turn, as it has in the past, on the procedural problem. The use of the class suit proper makes it feasible to give effective group redress to the old shareholders, if this be the desirable rule as a matter of substantive law.

27 § $16(\mathrm{~b})$ of the Fair Labor Standards Act, 52 Stat. 1069 (r938), 29 U.S.C.A. § 216 (Supp. I940). Numerous cases have been brought under this section; e.g., Fishman v. Marcouse, 32 F. Supp. 460 (Pa. 1940); Lengel v. Newark Newsdealers Supply Co., 32 F. Supp. 567 (N.J. I940); 2 C.C.H. Lab. Law Serv. T 23,258 . There is some danger that courts may drastically curtail the effectiveness of this section by misunderstanding the class suit provisions. See discussion (note 42 infra) of Saxton v. Askew Co., 35 F. Supp. 519 (Ga. I940).

28 "One of the more hopeful developments from the standpoint of the plaintiff has been the general trend under the impetus of the new Federal Rules of Civil Procedure toward joint or 
rivative suit is for the shareholder with respect to the misconduct of corporate fiduciaries.

The exact procedure envisaged for participation after the decree might be stated in somewhat greater detail, although the point is not a troublesome one. ${ }^{32}$ Bankruptcy, probate, equity practice in receivership, and fraudulent conveyance cases afford obvious analogies. The ordinary case will simply involve the common sense question of how best to bring everyone in and afford each one relief; clearly no exact rules of procedure are necessary or desirable, and there should be free play for the court's discretion.

In general the class suit will require the following additional steps: (I) The court should enter an interlocutory order in favor of the parties plaintiff of record and all those similarly situated who come in seasonably and establish their rights. (2) A reference should then be made to a master to administer the details of participation by the absentees. The defendant should be compelled by order to make available to the master all his information as to the names and addresses of the absentees. (3) The plaintiff's attorney or the master should prepare and submit to the court forms for proof of claims and accompanying explanatory material which the master should then mail to all absentees. (4) The absentees should file their claims within a prescribed time, and the defendant should be per-

representative action on behalf of the numerous parties who may have been injured by the same false report." Civil Liability Under the Federal Securities Act, 50 Yale L. J. 9o, 93 (I940); see Independence Shares Corp. v. Deckert, I08 F. (2d) 5I, 55 (C.C.A. 3 d x939), where the court stated that a suit pursuant to $\S$ I2(2) of the Securities Act of I933 was a class suit under Rule 23 (a) (3) of the Federal Rules of Civil Procedure. The Supreme Court, in passing on the case, did not rule on the class suit point. Deckert v. Independence Shares Corp., 6I S. Ct. 229 (1940).

${ }^{29}$ Spiller v. Atchison, T. \& S. F. R. Co., 253 U.S. $1 \times 7$ (x920); Cattle Raisers' Ass'n of Texas v. Chicago, B. \& Q. R. Co., Io I.C.C. 83 (rgo4). The opinion of Commissioner Prouty in this case is particularly worthy of study. Cf. In re Engelhard \& Sons Co., 23I U.S. 646 (rgr4); Bell Telephone rate litigation discussed in note 5 supra; Kovarsky v. Brooklyn Union Gas Co., 279 N.Y. 304, I8 N.E. (2d) 287 (1938).

${ }^{30}$ See, e.g., Harmon v. Auditor, 123 Ill. 122 (1887); Brown v. Trousdale, I38 U.S. $3^{89}$ (I89r).

${ }^{3 x}$ United States v. Old Settlers, $\mathrm{r}_{4} 8$ U.S. 427 ( 1893 ) (suit by American Indians).

${ }^{32}$ The ease with which a remedy was devised in suits to enforce bank stockholders' liability is illustrated in Golden v. Cervenka, $278 \mathrm{MI}$. 409 , $\mathrm{rr6}$ N.E. 273 (19I7), where it was held that the bank receiver was not a proper party to enforce the liability, but that the suit should be maintained as a creditor class suit and a special receiver appointed to collect the recovery. When the suits arose with frequency after the bank failures in the depression years, it became the practice to have the special receiver pay the recovery to the bank receiver for distribution. Cf. the procedure outlined by Commissioner Prouty in Cattle Raisers' Ass'n of Texas v. Chicago, B. \& Q. R. Co., Io I.C.C. 83 (I904). 
mitted to file objections, but only as to issues not common to the original plaintiff's case..$^{33}$ (5) The master's hearings should then be had as to the objections and, if relevant, as to damages of each claimant, and the master should file a report with the court in the customary manner. (6) The court, after disposing of all objections to the master's report, should enter a final decree ordering the defendant to pay all who have proved their claims and make provisions for expenses and fees. If the court finds that there may be a problem of collecting the judgment, it might enter the entire judgment in the name of the plaintiffs of record as trustees to collect and distribute to all who have proved claims; in such cases the court should reserve jurisdiction until the matter has been completely disposed of.

While this procedure seems quite simple, it probably represents the maximum complexity. ${ }^{34}$ Frequently, the process will be short circuited because the defendant may pay or be required to pay on the basis of his

33 Where the suit is predicated upon the existence of a common question of law or fact, it is often contended with considerable rhetorical force that there are so many individual questions involved that the suit cannot be maintained. This argument sometimes involves the implicit assumption that the class suit cannot be maintained if there are any individual questions. But normally it is the common question involved which presents the real issue in the case and the minor variations among the members are trivial or irrelevant.

There are several other points to be noted in de-emphasizing the importance of "individual" questions: $(x)$ Wherever there are relevant separate questions, they tend to become subordinate common questions, that is, common to a substantial minority of the class. (2) When the suit is conducted as a class suit, regardless of the variety of individual differences, the defendant is never deprived in any way of his right and opportunity to present any defenses arising from any of these individual variations. (3) It would seem that any attempt in a single proceeding to handle a variety of claims can never be more inconvenient to the defendant, or to the judicial system, than the litigation of each of these claims in a separate suit. (4) Finally, where the policy in favor of class litigation has been most clearly recognized as in the creditor distribution cases, the courts will endure almost any degree of inconvenience in handling the complete variety of individual claims to the end that a non-preferential distribution be made.

It is curious that courts, while holding that the individual questions are too varied to permit a suit to be maintained as a class suit, have nevertheless permitted the suit to continue on the basis of the joinder of the original parties. Cherry v. Howell, 4 F. Supp. 597 (N.Y. I93I).

34 It may be thought that if the defendant insists on a jury trial, the class suit procedure would become too cumbersome. In an ordinary multiple joinder case, the defendant is clearly not entitled to a separate and distinct jury trial on each claim. Akely v. Kinnicutt, 238 N.Y. 466 , I44 N.E. 682 (I924) (holding that although I93 plaintiffs had joined fraud claims, the defendant was entitled to only a single jury trial by a single jury). It follows necessarily that the most the defendant in a class suit can claim is a single jury trial as to those claimants who joined before the case was submitted to the jury and then, after solicitation and the absentees have come in, another single jury trial as to them. Further, it is not at all certain that the defendant's constitutional rights would be substantially impaired if he were precluded from re-trying as to absentees the common questions of fact determined by the first jury, leaving for new trial only the residue of new questions which in fact are apt to be negligible. 
own records. ${ }^{35}$ Again, the proving of claims may become almost nominal, as in the case of investors who need only show ownership of a security. Finally, there may be a proceeding, such as bankruptcy or receivership, pending concurrently, which will provide a ready vehicle for participation and distribution and need only be adopted. ${ }^{36}$

\section{III}

We have pointed out that the basic function of the class suit is achieved only if the decree is held open to permit the absentee members of the class to come under the decree after the decision and thus obtain the benefits of the litigation; and if under the auspices of the court the absentees can be solicited to participate.

It is appropriate at this point to consider Rule 23 of the Federal Rules of Civil Procedure, which presumably represents the summary and culmination of years of experience with the class suit. The history of the expert drafting of the rules, which were officially adopted by the Supreme Court of the United States in 1938 , is a familiar one. Rule 23 in particular has been widely regarded as a major achievement of the federal rules. ${ }^{37}$ Since the federal rules will serve both as a guide to the interpretation of existing state law and as a model for any future procedural changes, in a very real sense Rule 23 represents the law of the entire country..$^{38}$ The rule reads as follows:

35 In the bank stockholder cases it was the practice to use the bank's records in lieu of having each depositor file a claim. In Heine v. Degen, 362 IIl. 357 , I99 N.E. 832 (x936), it was expressly said that this procedure did not violate any constitutional rights of the defendants. Records were somewhat similarly used in Spiller v. Atchison, T. \& S. F. R. Co., 253 U.S. XI7 (r920), to determine shippers' reparation claims. In the Bell Telephone refund case (note 5 supra), the recovery was distributed voluntarily and at considerable expense by the company on the basis of its own records. The details of the refunding are set forth in 34 Ill. L. Rev. I 7 r, I72-73 (1939). In employees' class suits the same procedure for group distribution should be used in lieu of individual proof of claims wherever practicable. Where the Wage and Hour Division obtains restitution of back wages (note 9 supra), the distribution is normally made on the basis of the employer's records. See, e.g., 2 CCH Lab. Law Serv. I33,406 (1940).

${ }^{36}$ Chlupsa v. Posvic, $\mathrm{Ir}_{3}$ F. (2d) 375 (C.C.A. 7 th r940). In the Insull banks case (note 4 supra), the trustee in bankruptcy of Insull Utilities filed a cross-bill asserting that the bankruptcy of Insull Utilities vested the cause of action in him. When the case was settled, however, without determining this question, the trustee was appointed receiver in the creditors' suit to administer the distribution of the settlement moneys. As a practical matter he was thus able to adopt the bankruptcy machinery for distribution without requiring proof of claims in the creditors' suit. Cf. bank stockholder cases, note 32 supra.

37 "Rule 23 as to class actions is simple and intelligible, which is more than can be said of any rule that I know of heretofore promulgated either by statute or court rule." Sunderland, The New Federal Rules, 45 W. Va. L. Q. 5, I6 (I938).

${ }^{38}$ Considerable writing has been done on the topic. The standard treatment is 2 Moore, FederalPractice 2219-2303 (1938), discussed extensivelyinfra,pp. 702-707. See Lesar, Class Suits 
(a) Representation. If persons constituting a class are so numerous as to make it impracticable to bring them all before the court, such of them, one or more, as will fairly insure the adequate representation of all may, on behalf of all, sue or be sued when the character of the right sought to be enforced for or against ${ }^{39}$ the class is

(I) joint, or common, or secondary in the sense that the owner of a primary right refuses to enforce that right and a member of the class thereby becomes entitled to enforce it;

(2) several, and the object of the action is the adjudication of claims which do or may affect specific property involved in the action; or

(3) several, and there is a common question of law or fact affecting the several rights and a common relief is sought.

(b) Secondary action by shareholders. .....

(c) Dismissal or Compromise. A class action shall not be dismissed or compromised without the approval of the court. If the right sought to be enforced is one defined in paragraph (I) of subdivision (a) of this rule notice of the proposed dismissal or compromise shall be given to all members of the class in such manner as the court directs. If the right is one defined in paragraphs (2) or (3) of subdivision (a) notice shall be given only if the court requires it.

The rule contains no provision as to who is entitled to the benefits of the decree. Specifically, the rule neither authorizes holding open the decree for absentees, nor does it forbid it. It simply says nothing whatsoever.

and the Federal Rules, 22 Minn. L. Rev. 34 (r937); Moore and Cohn, Federal Class Actions, 32 711. L. Rev. 307,555 (I937); Moore, Federal Rules of Civil Procedure: Some Problems Raised by the Preliminary Draft, 25 Geo. L. Rev. 55I, 570 et seq. (I937); Wheaton, Representative. Suits Involving Numerous Litigants, I9 Corn. L. Q. 399 (I934); Recurrent Problems in Actions Brought on Behalf of a Class, 34 Col. I. Rev. II8 (I934); Blume, The "Common Question" Principle in the Code Provision for Representative Suits, 3o Mich. L. Rev. 878 (I932); Blume, Jurisdictional Amount in Representative Suits, r $_{5}$ Minn. L. Rev. 5or (r93 I). The best of the earlier discussions, however, is Pomeroy, Code Remedies $\$ \$ 388-4$ or (5th ed. 1929).

39 It will be noted that the Rule provides for suits against a class of defendants. It is believed that the defendant class suit is very different from the plaintiff class suit and would warrant an article in itself. Several points might be-briefly noted: ( $I$ ) if these suits are class suits in any sense, the judgment must affect absentees to the same degree as if they had been parties of record. A remarkable instance of a defendant class suit is afforded by Southern Ornamental Iron Works v. Morrow, ror S.W. (2d) 336 (Tex. Civ. App. r937) where money judgments were rendered against the absentees; (2) the historical origin of the class suit as a device to obviate compulsory joinder requirements is probably traceable to this type of suit; see infra, p.708. In these cases it might well have been impossible or impracticable to join all defendants; ( 3 ) the defendant class suit thus functions primarily as a substitute for service of process on the absentees where service is impossible because they are out of the jurisdiction or service is impracticable because they are so numerous. It is a striking commentary on constitutional requirements for service of process that a man cannot be validly brought under the court's power by a simple notice through the mails, yet can be bound by a judgment as a defendant in a class suit of which he may have had no notice whatsoever. It might be suggested that in many cases a liberalizing of the service of process rules by eliminating the archaic tagging requirement would seem more desirable and more compatible with due process than use of the defend- 
What is the status of participation under the rule? Despite the silence of the rule, it is reasonably clear that participation exists in every situation under sub-paragraph (a)(I). Clearly, there is recovery of the entire class in the shareholder's derivative suit, for the corporate entity interposes to collect the recovery for the shareholders as a class, and this disposes of the "secondary" right cases. Presumably, "common and joint" rights are used interchangeably and, presumably, "joint" is used univocally throughout the federal rules. Rule I9 on compulsory joinder establishes that in the cases of persons sharing joint rights, all must be joined, and this means that the cause of action is non-severable. Consequently, under Rule 23 , although representation is substituted for actual joinder, the cause of action in case of a joint right remains non-severable. Necessarily then, all who share this right, including the absentees, must be permitted to participate in the recovery. This same conclusion can also be based on the paragraph on dismissal and compromise, since notice to all parties is mandatory under the (a)(I) situation. Such a requirement can only mean that the absentees who must be notified are entitled to be heard and to participate in the benefits or burdens of the compromise. A fortiori, the same result obtains in the case of a favorable decree, apart from compromise. So much, then, for sub-paragraph (a)(I).40

The rule cannot be used so directly to support participation in subparagraph (a)(2), but the same result nevertheless obtains beyond doubt.

ant class suit; (4) the problem of procuring adequate representation is peculiarly serious in any large-scale suit. First, apparently the selection of representatives for the defendants is left to the plaintiff. Second, virtually none of the defendants may have any incentive to endure the expenses of defending a big suit on behalf of the entire class when the expense may be utterly disproportionate to his stake. Third, there is no easy way of compensating the defendants' counsel for the benefits conferred upon the class; see infra, p. 7I6; (5) the drafting of Rule 23 with respect to defendant class suits is subject to criticism. It would have been preferable to devote completely separate treatment to it. As the rule now stands, a defendant suit could apparently be brought under subparagraphs (2) or (3) although it is difficult to see what this would mean. Further, the representation and dismissal and compromise requirements are thus indiscriminately treated along with those in the plaintiff cases; (6) the most frequent examples of defendant class suits have been in unincorporated association cases where there may be considerable justification for the result because of the consensual representation. This is very similar to holding stockholders bound to a judgment in a suit against the corporation which was defended by the directors. Inter-class conflicts in corporations or associations present a genuine and troublesome problem. Smith v. Swormstedt, 16 How. (U.S.) 288 ( $x 853$ ), is an example. Cf. Purcell v. Summers, 34 F. Supp.42I (S.C. I940). Disputes between preferred and common shareholders as to arrearage plans would seem similar, but little attention seems to have been given to the need for defendant class suits in such cases; apparently, the corporation has been treated as representing the common as well as other classes of preferred.

10 Cases discussing participation in this situation are rare, but an excellent example is Backus v. Finkelstein, 23 F. (2d) 357 (D. C. Minn. 1927). 
This paragraph refers to the situations in which the court takes custody of property for the purpose of distributing it either according to pre-existing priorities or non-preferentially. Since the entire point here is one of effectuating a group distribution, all obviously can participate..$^{4 \mathrm{I}}$

It is with respect to the sub-paragraph (a) (3) suit, however, that the silence of the rule as to participation after decision proves genuinely troublesome..$^{2}$ It should be emphasized that except for certain stock-

42 Insofar as these cases are distinguishable from the other class actions the distinction is one between common distribution and common litigation. The best examples are afforded by statutory liabilities running to creditors where the liability will be exceeded by the claims of the creditors as a class. Here the courts uniformly permit class actions in order to effectuate a ratable distribution; note 79 infra. Until recent bankruptcy reforms, the equity receivership based on a creditors' bill on behalf of all creditors was widely used as a vehicle for corporate reorganizations. The popular notion that a "fund" is a basis for a class suit is derived from this distribution type of case. The chief interest of the common distribution cases today is as examples of a matured procedure for participation by an entire class.

${ }^{42}$ Case authority is unsatisfactory. There are numerous cases holding that "a class suit" is maintainable in this situation, but it is not clear what the court means by "a class suit." The plaintiff files on behalf of himself and all others, the defendant demurs or moves to strike, and the court decides for the plaintiff. These cases are difficult to interpret because the court decides the question without reference to any specific legal consequence such as whether participation will be permitted prior to decree, or after decree, whether the suit will be res judicata, etc., and it will be noted that since no one is seeking to intervene at the time of the defendant's motion, there is in a sense no actual issue before the court. E.g., Gramling v. Maxwell, 52 F. (2d) 256 (N.C. I93 I); Stephens v. Ohio State Tel. Co., 240 Fed. 759 (D.C. Ohio, 19 17); Thompson v. Deal, 92 F. (2d) 478 (App. D.C. I937); Jones v. Newton, 81 Colo. 25, 253 Pac. 386 (1927). There are occasional cases, however, dealing explicitly with participation after decree. In Atkins v. Trowbridge, I62 App. Div. x6I, I47 N.Y. Supp. 275 (I9I4), certain bondholders sued on behalf of all for damages occasioned by breach of a reorganization agreement. The court held that participation after decree was proper and permitted other bondholders to come in under the judgment. In a subsequent appeal on the merits in the same case, the court decided in favor of the defendants but elected to reconsider the question of participation and reversed its earlier decision. Atkins v. Trowbridge, I62 App. Div. 629, I48 N.Y. Supp. I8I (1914). The second opinion is curious for two reasons: the court was of the opinion that the suit was properly brought as a class action under the New York code provisions; the court also recognized that it was a familiar equity practice to permit absentees to apply at the foot of a decree for relief. Cf. Hendry v. Title Guarantee \& Trust Co., I65 Misc. 349, 300 N.Y. Supp. 74I (S. Ct. 1937).

In Kvello v. Lisbon, $3^{8}$ N.D. $7 x, 92,164$ N.W. 305,3 xo (I9I7), a taxpayer sued to enjoin a special assessment on behalf of himself and all others. The court, relying on Pomeroy, held that the decree should be held open for the others "... to come in and accept the benefit of the judgment...." Cf. Whaley v. Commonwealth, Ixo Ky. 154, 6r S.W. 35 (I90I). It might be noted that in both the Atkins and the Kvello cases, separate suits by the absentees would have been barred by the Statute of Limitations; note 88 infra. Pomeroy at least has clearly indicated that participation after decree is as much an incident of the common question suit as it is of the fund cases. Pomeroy, Remedies 295 et seq. (5th ed. r929). Cf. Backus v. Finkelstein, note 40 supra, and Cattle Raisers' Ass'n of Texas v. Chicago, B. \& Q. R. Co. and Spiller v. Atchison, T. \& S. F. R. Co., discussed in note $x_{3}$ supra.

Since the federal rules went into effect there have been no cases on participations after de- 
holder cases virtually every situation that is important socially involves nothing over and above common questions. Such random examples as employees' suits for back wages under the Fair Labor Standards Act, bondholders' suits on guaranties by third persons, shareholders' suits under the civil liability provisions of the various statutes administered by the SEC, damage suits under the anti-trust law, and suits by taxpayers, all involve the common question type of class suit. It is not too much to say that the construction of sub-paragraph (a)(3) with respect to scope of participation is pivotal to the social importance and utility of the class suit device.

Four persuasive arguments support the thesis that the decree in these cases will be held open to permit participation.

(I) The first is based on the construction of the major paragraph of (a) which provides that:

If persons constituting a class are so numerous as to make it impracticable to bring them all before the court, . . . one or more ... . may, on behalf of all, sue .... when the character of the right.....

Clearly then, sub-paragraph (a) (3) presents a situation in which the plaintiff represents the others in some sense, in which the others together with the plaintiff constitute a class in some sense, and in which the plaintiff sues on behalf of all in some sense. Yet if the other members of the class must become parties of record before trial if they are to participate at all, there is no sense in which the plaintiff either represents the others, or together with them constitutes a class, or sues on their behalf. Thus any construction which does not preserve some minimum residual meaning for the key words of the major paragraph when applied to sub-paragraph (a)(3) must be rejected. Moreover, we are also told by the rule that sub-paragraph $(\mathrm{a})(3)$ presents a situation wherein "the parties are

cree, although in Alabama Independent Service Station Ass'n. v. Shell Petroleum Corp., 25 F. Supp. 386, 390 (Ala. r939) the court said: "However, for the recovery of damages, each member of the class must intervene to assert and prove such damages to himself."

Cases of interest have arisen under the wage and hour law. Saxton v. Askew Co., 35 F. Supp. 5 Ig (Ga. I940); Brooks v. Southern Dairies, Inc., 3 C.C.H. Lab. Law Serv. If 60, 438 (D.C. Fla. I94I). While the opinions are unclear and difficult, it would seem a fair inference that the courts would restrict recovery to employees who had intervened and become parties of record prior to judgment. Such a limitation on the scope of the class suit is particularly unfortunate where the court had not only Rule 23 but an express mandate from Congress in $\$$ I6(b) of the wage and hour law. The language of the court in the Brooks decision is especially worthy of note in the year I94I: "I deem it beyond the power of Congress to force one to become plaintiff against his will or to select for him an agent or attorney to represent him. I further am of the opinion that the employee has the right to determine whether or not he wishes to sue his employer. ...." 
so numerous as to make it impracticable to bring them all before the court." But if the other members of the class must become parties of record before the trial, the rule is reduced to saying that where it is impracticable to bring all the parties before the court they must nevertheless be brought before the court. Finally, if Rule $23(\mathrm{a})(3)$ merely permits participation before the decree and not after, it is gratuitous and adds not one iota to Rules I9 and 24 on permissive joinder and intervention.

(2) This argument is based on paragraph (c) regulating dismissal and compromise, which, it will be remembered, requires that, "A class action shall not be dismissed or compromised without the approval of the court." In an ordinary law suit the court does not pass on a compromise despite the number of persons who may have joined as plaintiffs. The explanation for making any compromise the concern of the court in cases under subparagraph (a) (3) must lie in the intention to protect the absentee members of the class and to make the compromise available to them. ${ }^{43}$ The notice provisions in paragraph (c) tend to much the same result, although they are not conclusive in that the giving of notice to all is discretionary with the court. ${ }^{44}$ To the extent that the rule provides that the court can give notice to absentees, there is clear recognition of their rights to participate in the compromise, and by inference this is true in the event of a favorable decree as well, since there would be no point in distinguishing compromise from decree.

(3) This argument is closely allied to the first. Participation is clearly a characteristic of the suits under sub-paragraphs (a)(I) and (a)(2). Since type (3) class suits are by the terms of the rule equally in the same category with types (I) and (2) as representative actions, characteristics present in the first two would clearly belong to the third as well, under ordinary canons of construction, unless there is an express discrimination against (3). The rule does not expressly state that sub-paragraph (a)(3) is to differ in this respect; there is nothing to rebut the presumption that all three types of class suits are alike with respect to participation.

(4) The fourth and final argument need be only briefly summarized. If the rule does not too clearly permit participation after the decree, it most certainly does not prohibit it. At the very least then the question is com-

43 It might be thought that instead the purpose is to protect them from the res judicata aspect of the compromise, but this would only further prove that they were entitled to participate in the compromise. Clearly, they could not be held bound by a compromise and yet not be afforded the opportunity to participate in it. Furthermore, the decree in the (a) (3) situation has traditionally been thought not to be res judicata on absentees; note 84 infra.

44 Frequently, notice to the absentee may not be necessary to participation since recovery can be distributed on the basis of the defendant's records; see note 35 supra. 
pletely open. But under these circumstances, the policy considerations which have been a familiar refrain throughout this article virtually compel the construction that participation by absentee members is permitted after the decree. That this must be so is evident if the real argument of the defendant is made explicit. The court has just decided that the defendant is liable to those in the same legal position as the plaintiff. The defendant in resisting participation must contend not that he is not liable to the others, but that each must endure the normal inconvenience of litigation, that each must harass him with a separate suit, and ultimately, that justice has been made too quick, too convenient, too exact, and too complete. ${ }^{45}$

\section{IV}

Despite the silence of the rule on the point, ${ }^{46}$ the arguments construing the rule to permit participation after decision are powerful even where the class is constituted only by virtue of a common question of law or

15 One other possible difficulty with the suggested construction of Rule 23(a)(3) warrants brief comment. This section requires not only that there be a common question but that common relief be sought. The question arises as to whether money damages, which will be the most frequently sought remedy in the cases that have been discussed, are a form of common relief. There are frequent suggestions that money damages are not comparable to injunctive or declaratory relief and that common relief properly encompasses only the latter two. Kovarsky $v$. Brooklyn Union Gas Co., 279 N.Y. 304, I8 N.E. (2d) 287 (1938) (holding that plaintiff's class action was proper as to injunctions and declaratory judgment but not as to an accounting); Sunderland, op. cit. supra note 37, at 16-17. It may further be contended that if common relief includes damages to each individual claimant it becomes meaningless.

But the feeling that there is a radical difference between an injunction and damages as common remedies is illusory. The difference is simply one of the degree of convenience in making available the benefits of the litigation to the class. Normally, the injunction cases represent the maximum convenience of administration; the decree will ordinarily protect the absentees since it is entered in the names of the class generally. Cf. Kvello v. Lisbon, 38 N.D. 71,164 N.W. 305 (I9I7) (decree in injunction suit was held open to permit absentees to come in and apply for relief under it). But as has been seen the mechanics for the money damage cases are quite simple. Thus, the rule can scarcely be taken to mean that where little or nothing need be done by the members of the class to participate, the relief is common, but where a little more need be done the relief is not common. Further, since injunction and declaratory judgment are well understood terms and since common relief is not, presumably the draftsmen would have employed the more readily understood terms if that is what they had meant. Again, the term is not meaningless if taken to include money damages. What it in all probability means is relief from a common source, namely, the same defendants. The point has been litigated trrice under the rules and on each occasion the court has held that money damages constituted common relief. Independence Shares Corp. v. Deckert, ro8 F. (2) 5I, 55 (C.C.A. $3 \mathrm{~d}$ 1939) ("Common relief may be sought despite the fact that individuals may recover separate judgments different in amounts"); Alabama Independent Service Station Ass'n v. Shell Petroleum Corp., 28 F. Supp. $3^{86}$ (Ala. 1939); this is apparently Moore's view. 2 Moore, Federal Practice 224I (1938).

46 Rule 24(b) providing for permissive intervention upon "timely" application in cases of common questions might possibly be used to support participation after decree. It would seem 
fact. The case might seem closed were it not for one additional piece of evidence. That evidence is the commentary of Professor Moore of Yale University Law School on the rules and on Rule 23 in particular. ${ }^{47}$ Professor Moore's commentary is of unique importance, for not only has he edited the most exhaustive treatment of the new federal procedure, but he was also personally instrumental in drafting the rules and thus can be taken as a witness of authority as to the intentions of the draftsmen. Professor Moore, in his treatment of Rule 23, places the primary emphasis on the classification into three kinds of class suits rather than on the characteristics of the class suit in general.

"The classification which the Rule makes," Moore tells us, "is dependent upon the jural relationships of the members of the class." ${ }_{48}$ And again: "A classification of the factual situations which are recurrent in this type of litigation in terms of jural relations formulated the problem more incisively." 49 The type ( $x$ ) situation seems to work out well enough. Here the jural relation between the members is one of sharing "a joint, common, or secondary right." Unfortunately, this principle of classification breaks down in the other two categories, for in each the jural relation between the members is the same: they have several rights, and it is something else which operates to separate them-specific property in the one case and a common question in the other, and neither specific property nor a common question are jural relations in any ordinary sense.

This, however, may seem to be of interest chiefly to the logician, since Moore is quite clear as to the specific content of each species. The three kinds are named respectively "the true, the hybrid and the spurious" and are identified as follows:

(i) the true class suit. This represents the compulsory joinder notion of the class suit. "The true class suit," Moore tells us, "is one wherein, but for the class action device, the joinder of all interested persons would be essential."so

\footnotetext{
more probable, however, that Rule 24 is confined to intervention prior to trial, since the intervenor must plead formally.

Conversely, it might be noted that limiting Rule 24 to intervention prior to decree does not affect participation after decree under Rule $23(\mathrm{a})(3)$. Clearly, participation is permitted under Rule $23(a)(1)$ and (2), yet intervention in the sense of Rule 24 is restricted by Rule $24(a)(2)$ to cases of inadequate representation. This indicates rather clearly that coming in after the decree merely to participate is not intervention within the meaning of Rule 24 .
}

47 See writings of Moore, note 38 supra.

${ }^{48} 2$ Moore, Federal Practice 2235 (1938).

49 Ibid., at 2230 . In footnote 7 on this page he states that the three types are "differentiated by the character of the rights involved."

${ }^{\circ}$ Ibid., at 2236; see, in general, ibid., at 2235-39. 
(ii) the hybrid class suit. It is quite clear that this represents the "fund" notion of the class suit..$^{5 x}$ In this case Moore states ". . . there is ... . the presence of property which calls for distribution or management."52

(iii) the spurious class suit. "This," Moore explains, "is a permissive joinder device." 53 The plaintiff by the words "on behalf of himself and all others" invites absentees to join in the suit by intervening.

So construed, the rule is emptied of much of its importance. Merely avoiding the rigors of compulsory joinder-the function of the true class suit according to Moore-is today on any terms trivial and would have warranted only the addition of a line or two to Rule I9(a) dealing with compulsory joinder. The class suit in this conjunction represents a procedural reform antedating the rule by at least three centuries. ${ }^{54}$ It is curious that Moore, after clearly setting forth that the class suit arose historically as an "escape rule" made necessary by the restrictions of compulsory joinder, ${ }^{55}$ deprecates at a later page the old "common or general interest" requirement of Equity Rule 38, which the new Rule 23 replaces, as reflecting "at most the historical birthplace of class suits," "56 and at a third page goes on to applaud the translation of the true class suit back into compulsory joinder terms. ${ }^{57}$ The hybrid class suit does not fare much better. Moore tells us: "The action is unique but its importance is decreasing." ${ }_{58} \mathrm{He}$ explains that bankruptcy and reorganization statutes have virtually preempted the field.59

The spurious suit fares most poorly of all. To the extent that it is a permissive joinder device, it is utterly gratuitous, since, as earlier pointed out, ${ }^{60}$ the identical function is already performed by the liberal

sx Note $4 \mathrm{x}$ supra.

${ }^{52} 2$ Moore, Federal Practice 2240 (1938); see, in general, ibid., at 2239-4r.

53 Ibid., at 224I; see, in general, ibid., at 224I-45.

54 See Chancey v. May, Prec. Ch. 592 (I722); and see remarks of Lord Eldon in Cockburn v. Thompson, I6 Ves. 32 ( $\mathrm{Ch}$. I80g). One of the earliest cases, Brown v. Vermuden, I Cas. in Ch. 272 ( 1676$)$, involved a suit against a class of defendants. As to this type of class suit see note 39 supra.

552 Moore, Federal Practice 2224 ( $\left.x_{938}\right)$. $\quad{ }_{56}^{6} \mathrm{Ibid}$., at 2230.

57 "Various tests have been proposed to determine whether a suit was a true class action. The doctrine .... that beneficial proprietary rights are the determinative factor of the propriety of class suits has fallen into disrepute. So has the doctrine that the presence of a fund is the determinant. These efforts at nomenclature are, however, significant. They illustrate the desire of courts to find a unity of interests between the parties. This can be expressed better in terms of joinder. The true class suit is one wherein but for the class suit device the joinder of all interested persons would be essential." Ibid., at 2235-36.

${ }^{88}$ Ibid., at 2239.

s9 Tbid. ${ }^{60}$ See supra, p. 700. 
rule on permissive joinder and the rule on permissive intervention. ${ }^{6 x}$ Moore states this difficulty with clarity. After commenting on the refusal of some courts to permit the spurious class actions in tort cases, he points out: "In those jurisdictions there is no need for the class action for the injured parties can join as plaintiffs under the common question of law or fact provisions. ...." ${ }^{\prime 62}$

Under the federal procedure, however, there is one function assigned by Moore to this third type of class suit which we have not as yet disclosed. ${ }^{63}$ It is a well-established rule that in cases of permissive joinder each party must independently satisfy the familiar prerequisites to federal jurisdiction. ${ }^{64}$ Moore states that in the spurious class suit these prerequisites need be met only by the original parties and that thereafter intervenors may come in regardless of their citizenship or the amount of their claim. ${ }^{65}$ This saving function for the type (3) suit is at once irrelevent to the purpose of the class suit, trivial, and probably unsound. ${ }^{66}$

6x Cf. Clark, Code Pleading 280 n. 202 (I928).

${ }_{62} 2$ Moore, Federal Practice 2244 (1938) (Italics added).

${ }^{63}$ Ibid., at 2245 : ". . . . but in the federal courts . . . . the spurious class action can be justified." (Italics added.)

64 Pinel v. Pinel, 240 U.S. 594 (IgI6) (separate amount in controversy for each party plaintiff); Strawbridge v. Curtiss, 3 Cranch (U.S.) ${ }_{26} 6$ (I806) (complete diversity).

$65_{2}$ Moore, Federal Practice 2245, 2295 et seq., 24I2 (1938).

${ }^{6}$ So considered the type (3) suit functions exclusively as a trick for obtaining federal jurisdiction. The suit would thus have no function in federal question cases which supply the preponderance of class actions, nor in state courts, and it would be somewhat difficult to account for the frequency of such suits where there is no problem of federal jurisdiction or to understand why Congress provided for class suits in the wage and hour law.

The rule would be absurd as stated since an original party of record who lacked the jurisdictional prerequisites can go out and come in a moment later as an intervenor. And again, federal jurisdiction would still not be available unless at least one of the various parties had the federal prerequisites. Nor is adequate authority cited for this result. The only case referred to is Stewart v. Dunham, II5 U.S. 6I (1885), involving a general creditors' bill to set aside a fraudulent conveyance, which indicated that a creditor could subsequently intervene even though he himself did not satisfy the diversity of citizenship requirement. The court had to permit the intervention or dismiss the suit altogether, for if it denied intervention and continued the suit, the creditor's claim against the property would be barred. Hence, it is not surprising that it did not permit intervention to defeat jurisdiction. Apparently Moore reached this result in the spurious class suit by assuming that the choice again was to permit intervention or to dismiss the suit. But this ignores the possibility that the court could simply deny intervention since the intervenor would not be prejudiced thereby as he would have been in the Dunham case. The more desirable result would be to relieve the class suit of federal jurisdictional requirements designed for individual suits. Clearly, there is no genuine problem as to amount in controversy. If the class is to be permitted to recover, the amount should, of course, be measured by the recovery to the class as a whole. Cf. Gorley v. City of Louisville, $23 \mathrm{Ky}$. L. ${ }_{77} 82,65$ S.W. 844 (r9or); this position is ably urged in Blume, Jurisdictional Amount in Representative Suits, I5 Minn. L. Rev. 501 (I93I). It must be admitted, however, that the federal 
In summary, the rule performs three functions as interpreted by Moore. That of the "true" class suit, no one any longer cares about; that of the "hybrid" suit is well taken care of through another procedure entirely, and the "spurious" simply duplicates a task already performed by another section of the rules.

It may be contended that Moore's tripartite classification becomes quite clear and simple if related to res judicata and that the basic difference between the three kinds of class suits can be readily stated in such terms. There is little doubt that Moore understands the three species to be keyed to res judicata. ${ }^{67}$ At one time the draft of the rule contained a section on the effect of judgment which was subsequently omitted only because the draftsmen were afraid that the effect of judgments is so substantive in character as to go beyond the Congressional warrant to draft rules of procedure. ${ }^{68}$ Moore paraphrases this erstwhile section as follows:

The judgment rendered in the first situation [the true class action, Rule $23(\mathrm{a})(\mathrm{I})$ ] is conclusive upon the class; in the second situation [the hybrid class action, Rule $23(a)(2)]$ it is conclusive upon all parties and privies to the proceeding, and upon all claims, whether presented in the proceeding or not, insofar as they do or may affect specific property, unless such property is transferred to or retained by the debtor affected by the proceeding; and in the third situation [the spurious class action, Rule 23 (a)(3)] it is conclusive upon only the parties and privies to the proceeding.69

Each species thus differs with respect to the degree of res judicata, and we have a key to his names- "the true, the hybrid, and the spurious."

rule is the other way. Russell v. Stansell, 105 U.S. 303 (I88I); Scott v. Frazier, 253 U.S. 243 (1920); Cohn v. Cities Service Co., 45 F. (2d) 687 (C.C.A. 2d I930). It is possible that Pinel v. Pinel, 240 U.S. 594 (xgr6), cannot be successfully distinguished as applied to class suits. It was undoubtedly designed to check excessive resort to the federal courts in the days of Swift v. Tyson. Now that Swift v. Tyson has been overruled there is no longer a need for the courts to be so vigilant to limit federal jurisdiction inasmuch as a substantive law difference cannot be obtained in the federal courts. It would seem appropriate to treat the $\$ 3,000$ limitation as insuring simply that petty cases be kept out of the federal courts.

Much the same considerations apply to the diversity requirements. If complete diversity is to be required literally in these large group cases, federal jurisdiction becomes an impossibility. The courts long ago abandoned literal compliance with the requirement in corporation cases. First, all shareholders of the corporation were conclusively presumed to be citizens of the state of incorporation, and then even when a derivative suit was brought the courts were willing to treat the plaintiff shareholders as simultaneously of the same state and yet of a different state than that of the corporation in order to permit such suits in the federal courts. An illuminating discussion of this development is found in Gray, The Nature and Sources of Law I84-86 (2d ed. I921). It should probably be sufficient if there is an allegation that some members of the class are of a different state than the defendants; and in any event, it should be sufficient if the parties plaintiff of record supply diversity.

${ }^{67} 2$ Moore, Federal Practice 2235, 2283 et seq. ( $\left.193^{8}\right)$.

${ }^{68} \mathrm{Ibid}$., at 2283 . $\quad 69$ Ibid., at $2294-95$. 
The true class suit is true because the decree is one hundred per cent res judicata as to absentees; the hybrid class suit is hybrid because the decree is only about fifty per cent res judicata, and the spurious class suit is spurious because the decree is not res judicata on absentees at all.

However simple this may seem, there are two diffculties with keying the rule to res judicata: the rule as drafted becomes at once incoherent and unimportant. If the rule is keyed to considerations of res judicata, its primary purpose is then to indicate the varying scope of res judicata. But whatever the draftsmen may in fact have intended, the rule does not say anything about res judicata. Since the rule is silent, it does not regulate the courts in any manner with respect to res judicata. The rule in effect says: "In the following three situations, no opinion is expressed as to what should happen." Hence, as a res judicata rule it is utterly meaningless, since the courts are as free "under" the rule as they would be without it. No court, for example, which held that the decree was res judicata in the spurious suit could conceivably be said to violate the rule. Rule 23 then is not a rule at all; at most it is a restatement of law somewhat comparable to the volumes of the American Law Institute, or better, a caveat therein..$^{70}$

And as an ironic after-thought, if the committee were correct that the effect of judgments is a matter of substantive and not of procedural law, under the doctrine of Erie R. Co. v. Tompkins, ${ }^{7 x}$ the effect of res judicata is left to the discretion of the state courts..$^{72}$ The federal rule is thus reduced to the anomaly of a mere prediction as to a point of substantive law in the forty-eight states. The final difficulty is the status of the spurious class suit in these terms. If those suits are classified in terms of res judicata on absentees, clearly a suit wherein the decree is not res judicata on absentees at all is not properly included-it has no more in common with the true and the hybrid class suits than any random suit whatever,

${ }^{70}$ Moore does not ignore this difficulty, but suggests that the omission of express provisions as to the effect of judgment has its advantages: "On the other hand, there is a certain danger in trying to freeze the effect of judgment in rules: the flexibility of case treatment may be more desirable." Ibid., at 2284 . He then proceeds to restate the case law on the effect of judgment flatly in terms of the committee's proposed section. It might also be observed that he states: "In some instances courts have determined the conclusiveness of decrees only after they had first decided whether the absentee parties had notice of the suit. Such an 'analysis' seems, at most, to be relegating the entire doctrine to the haphazardous concept of 'fireside equity.' Only confusion has resulted from such a criterion." Ibid., at 2294. See discussion of res judicata, infra, pp. 7ro-I4.

${ }^{7 x} 304$ U.S. 64 (I938).

$7^{2}$ Query as to what would regulate the effect of judgment in cases involving federal questions such as those arising under the securities act, the anti-trust laws, and the wage and hour law? 
which is, of course, not binding on utter strangers to it. Further, to key the class suit to res judicata on absentees is to give it a very limited function indeed. Res judicata in these cases amounts to nothing more than the quieting of claims against defendants. Surely the plaintiff does not make his suit a class suit in order to assist the defendant in quieting the claims of absentees; and usually the defendant actively contends that no class suit is maintainable and therefore argues against conferring upon himself this supposed primary benefit of the class suit.

The difficulty with Moore's interpretation arises because he has discussed the rule in procedural terms and not from the viewpoint of providing an effective and inclusive group remedy, and thus he has inadvertently given it a sort of Rule-in-Shelley's-Case look. But it must be admitted that the distinction between "true," "hybrid," and "spurious"73 class suits, which is the source of his difficulties, is not entirely of Moore's own making. ${ }^{74} \mathrm{He}$ has attempted rather to restate the law on class suits, preserving a traditional emphasis on two concepts, compulsory joinder and res judicata. It is this general assumption that there cannot be a genuine class suit where there is neither compulsory joinder nor a decree which is res judicata on absentees that has prevented realization that the common-question class suit, which possesses neither characteristic, nevertheless possesses a social importance and effectiveness coordinate to that of the few class suits which have both these characteristics. Compulsory joinder and res judicata have for so long been thought to be intimately related to the class suit that the relevance of each concept warrants a separate examination at this point.

Compulsory joinder and the class suit. It is generally said that the class

${ }^{3}$ It may be salutary and perhaps refreshing to pause for a moment to write an epitaph for Moore's accursed labels, "true," "hybrid," and "spurious." It may be a matter of concern only to the purist that this terminology is ludicrous and that the plaintiff must stubbornly insist that he has a spurious suit against the equally stubborn insistance of the defendant that it is not spurious; it may be a matter of concern only to the West Publishing Company that the phrase "spurious class suit held maintainable" must now appear in head notes; it may be a matter of concern only to the logician that we are given three species of class suits the first of which is really a class suit, the second of which is partly a class suit, and the last of which isn't a class suit at all; but it is a matter of general concern that so perverse a value judgment is expressed by this application of the terms "true" and "spurious" to suits of equivalent social importance and function. Given the penchant of the legal mind for psittacistic repetition of labels -res gestae, res ipsa loquitur, champerty and maintenance, or power coupled with an interest, for example-it is imperative that the class suit of sub-paragraph (a)(3) be saved from the damnation of the faint, faint praise carried by the word "spurious."

74 Compare the origins of Rule 42 in Carroll, Alice in Wonderland I8I-82 (Peter Pauper Press ed.). 
suit had its origins in the desire of the courts of equity to mitigate certain rigors of the rules of compulsory joinder. In a recent Supreme Court decision Mr. Justice Stone has summarized the orthodox theory:

The class suit was an invention of equity to enable it to proceed to a decree in suits where the number of those interested in the subject of the litigation is so great that their joinder as parties in conformity to the usual rules of procedure is impracticable. Courts are not infrequently called upon to proceed with causes in which the number of those interested in the litigation is so great as to make difficult or impossible the joinder of all because some are not within the jurisdiction or because their whereabouts is unknown or where if all were made parties to the suit its continued abatement by the death of some would prevent or unduly delay a decree. In such cases where the interests of those not joined are of the same class as the interests of those who are, and where it is considered that the latter fairly represent the former in the prosecution of the litigation of the issues in which all have a common interest, the court will proceed to a decree. 75

While this history may serve to explain how compulsory joinder and class suits were originally brought together, it affords no clue as to why they are still together. However sound may be the historical explanation of the origin of the class suit, compulsory joinder as a test to determine when a class suit can be brought is today singularly inappropriate. Used as a test, it yields the curious formula that where there is no occasion for compulsory joinder, there is no occasion for the class suit. But it should be remembered that where a plaintiff may sue alone, there is in turn no occasion for compulsory joinder. Thus rephrased, the formula tells us that where the plaintiff may sue alone, he cannot sue for others as well. Consequently, a plaintiff who does not want to sue alone but prefers to sue for others is told that he cannot sue for others because if he had wanted to sue alone, he could have.

The non sequitur here need not be labored further. There is, however, one other notable aspect of the use of the compulsory joinder criterion. If the modern development of the class suit is to be hitched to compulsory joinder, the class suit is virtually doomed. Compulsory joinder requirements have everywhere been relaxed, and the number of compulsory joinder cases is rapidly diminishing. On the compulsory joinder test, then, the number of occasions for the class suit must similarly be diminishing.

It may be suggested that there is another possible view of compulsory joinder which gives it a relevance to the modern class suit and at the same time makes the history of the class suit less fortuitous. ${ }^{76}$ The sug-

${ }_{75}$ Hansberry v. Lee, 3 II U.S. 32, 4I (x940).

${ }^{76}$ The historical development of the class suit is fortuitous if it is true that the courts were concentrating on fashioning an "escape" device for relieving the plaintiff of compulsory joinder requirements when they developed a powerful form of group redress. 
gestion is that the class suit in lieu of compulsory joinder of plaintiffs may be regarded not as an escape device, but as an expression of a policy in favor of class suits so strong as to compel the individual plaintiff to sue on behalf of all. It should first be noted that there is a decided difference between compulsory joinder of plaintiffs and compulsory joinder of defendants. In regard to defendants it may well be impossible to determine the plaintiff's rights without at the same time adjudicating or affecting the rights of others adversely situated to him. Here, there is literally necessary joinder. But an equivalent necessity never obtains in the plaintiff cases. The court can always permit the plaintiff to sue alone and limit its decree to him alone. This fact is illustrated by the ease with which legislatures in numerous states have transformed joint rights into joint and several rights so as to enable the plaintiff to sue alone. ${ }^{77}$ In the few examples of compulsory joinder of plaintiffs, it is clear that nothing in the nature of things prevents the court from determining the single plaintiff's rights alone; something else must require the class suit in these cases. Consider, for example, a suit by a shareholder to compel the declaration of a dividend..$^{8}$ Clearly a court could limit its decree to the plaintiff alone without in any way prejudicing or otherwise affecting the rights of the other shareholders equally entitled to a dividend. Each might be left to sue for himself when he chose and if he could. But the court adjudicates the entire controversy, not because it must but because it wants to and because it is apparently thought more consonant with the policy of corporation law to afford all the shareholders at once an efficient remedy.

If the class suit in lieu of compulsory joinder is viewed as an escape device designed to enable the selfish plaintiff to maintain his suit, it is an anachronism. If, however, it is viewed as a device to compel the plaintiff to make his knowledge available to all and to sue on behalf of all, it affords an example of an extreme policy in favor of remedies for the group as a unit. The compulsory joinder class suit cases consequently amount to nothing more than a common question plus a strong policy in favor of a remedy for the group. ${ }^{79}$ It might well be appropriate for the courts

772 Williston, Contracts $\$ \S 336-336 \mathrm{~A}$ (rev. ed. I936).

${ }^{8}$ Cases in which courts have held the withholding of dividends by directors an abuse of discretion are infrequent. But see Channon v. Channon Co., 218 Ill. App. 397 (I920).

${ }^{79} \mathrm{Cf}$. the classic statement as to when joinder is necessary in Shields v. Barrow, I7 How. (U.S.) ${ }^{*}{ } 30,{ }^{*}{ }_{3} 9$ (I854). In creditor cases where there is a policy in favor of non-preferential distribution there has long been this notion of the mandatory class suit. An interesting line of decisions developed in Illinois interpreting provisions of the old corporation statutes imposing liability on directors for permitting the corporations to incur indebtedness beyond the stated 
to extend this notion of mandatory class suits to situations where joinder has never been compulsory, as for example, the Securities Act cases. If it is desirable that the class suit be mandatory where stockholders sue for breach of fiduciary duties by directors, ${ }^{80}$ or where they sue to compel declaration of dividends, it is difficult to see why the same result should not obtain where the suit is founded on a violation of the Securities Act. Compelling the plaintiff to turn public representative, however, is a sanction that should be exercised judiciously and sparingly, and in any event the inquiry should be into such factors as the availability of the plaintiff's knowledge to others similarly situated, the probable delay to the plaintiff, the size of the claims, and the degree to which the class is scattered. ${ }^{8 x}$

Res judicata and the class suit.-It is a basic tenet of Anglo-American law, that the rights of no man should be barred without his having had a day in court. Yet this is apparently the result of a decree in a class suit .held to be binding upon absentee members, and this result is supported

capital. In Low v. Buchanan, 94 III. 76 (I879), the court refused to permit a single creditor to sue at law to enforce this liability under the act of $r 872$ and held that his only remedy was a class suit in equity. In Pick \& Co. v. Warshauer, 244 Ill. App. 56 (I927), a single creditor again sued on behalf of himself alone and contended that the omission of the words "to the creditors" in the act of IgIg had changed the rule of the Low case. The court said: "We do not so conclude. The above-mentioned decisions were not based upon the presence or absence of the words 'to the creditors,' but upon fundamental reasons of justice and expediency." Ibid., at 58. Moore seems to explain similar statutory liability to creditors as predicated on "joint or common" rights. 2 Moore, Federal Practice 2238 (I938).

It is true, of course, that since the creditors cannot sue alone to enforce the statutory liability, they have "joint" or "common" rights; but this is solely a conclusion based upon the policy consideration of avoiding preferences. Under the I933 Business Corporation Act the liability of directors for declaring dividends impairing capital and thus injuring creditors runs to the corporation. IIl. Rev. Stat. (1939) c. $32, \S 157.42$. At least one reason for this change is the procedural convenience of the corporate form. Ill. Bus. Corp. Act Ann. I63 (I934).

${ }^{80}$ The derivative suit, of course, is a mandatory class suit. The leading case, Smith v. Hurd, I2 Metc. (Mass.) 37 I (I847), is interesting reading in this connection. The policy of conferring the benefits of the litigation on all shareholders may perhaps be the best reason for the refusal of the Courts to allow individual suits by shareholders even in the special duty cases. For a collection of cases, see Personal Recovery by Shareholders for Injury to Corporation, 2 Univ. Chi. L. Rev. 3 I 7 (1935).

8x Unless such class suits were made compulsory by statute, it may be somewhat difficult to see how the issue would be raised, since it is to the defendant's advantage to have the plaintiff sue alone. The history of litigation would seem to show, however, that any argument opposite to the plaintiff's seems a good one to the defendant. It is a certainty that if a shareholder were to attempt to sue for himself alone on a corporate cause of action, the defendant would object. Further, courts may act on their own motion and require the class suit. Cf. Tyndall v. Pinelawn Cemetery, I98 N.Y. 2I7, 9I N.E. 59I (IgIO). And there are some striking examples of courts raising legal points ignored by the parties. Erie R. Co. v. Tompkins, 304 U.S. 64 (1938); Thompson v. Magnolia Petroleum Co., $3 \circ 9$ U.S. 478 (1940), noted in 7 Univ. Chi. L. Rev. 727 (I940). 
by several striking decisions of the United States Supreme Court. ${ }^{82}$ Undoubtedly it is because holding the absentees bound is so extraordinary a deviation from the traditional rules of due process, that the res judicata aspect of class suits has received so much attention and that this incidental characteristic has been mistaken for the essence of the class suit. ${ }^{83}$

But there is no necessary connection between the class suit and res judicata, and it is perfectly proper to permit all to participate in a favorable decree in a class suit even though, had the suit been unsuccessful, they would not have been bound by it. To sharpen the point at issue, it is agreed that in most cases in which the class suit would be useful socially, that is, cases involving nothing more than common questions of law or fact, the decree under current authority is clearly not res judicata as to the absentees. ${ }^{84}$ If, then, it is indispensable that participation after decree be permitted only where the decree would be res judicata, the scope and utility of the class suit, as we have been discussing it, will be drastically reduced.

Considered directly the question of participation after decree admits a ready and adequate answer which is quite possible without any reference to res judicata. Obviously it is only if the parties can thus participate that the social utility inherent in the device can be realized-all will be afforded inexpensive, certain, adequate relief. And what is more, the threat that the size of a judgment may so readily expand will have a desirable inhibitory effect. In fact, the one-sidedness of the question is best indicated by recurring once again to the argument the defendant is forced to make. As was said before, he must contend, not that he is not liable to the absentees, but that each absentee must endure the normal inconveniences of litigation, and harass him with a separate suit.

Further, not only can the court decide the question of participation without reference to res judicata, but it is most difficult to see what aid it gets from referring to res judicata. It would seem to be posing a purely

${ }_{82}$ Supreme Tribe of Ben-Hur v. Cauble, 255 U.S. 356 (I92I); Hartford Life Ins. Co. v. Ibs, 237 U.S. 662 (1915); Hartford Life Ins. Co. v. Barber, 245 U.S. 146 (I917); there is a dictum to this effect as early as Smith v. Swormstedt, I6 How. (U.S.) *288 (I853). The decisions are carefully collected and reviewed in the opinion in Hansberry v. Lee, 3 II U.S. 32 (I940). For decisions subsequent to the federal rules, see Waybright v. Columbian Mutual Life Ins. Co., $3 \circ \mathrm{F}$. Supp. 885 (Tenn. I939); Purcell v. Summers, 34 F. Supp. 42 I (S.C. I94O).

${ }^{83}$ Even in Arnold and James, Cases on Trials, Judgments, and Appeals I69 et seq. (1936).

${ }^{8} 4$ Wabash R. Co. v. Adelbert College, 208 U.S. 38 (Igo8); First Nat'l Bank of Florence v. Edwards, ${ }_{34}$ S.C. 348 , I32 S.E. 824 (1926); cf. Ayer v. Kemper, 48 F. (2d) II (C.C.A. 2 d I93I), cert. den. 284 U.S. 639 (I93I). We do not accept the alternative suggested in Recurrent Problems in Action Brought on Behalf of a Class, 34 Col.L. Rev. II8 (I934), that the decree in all class suits be made res judicata. 
hypothetical question: if instead of a favorable decree a decree of dismissal had been entered and if an absentee had subsequently brought a separate suit against this defendant, then would he be barred by the hypothetical decree of dismissal? Such a hypothetical question may well be a good deal more difficult to answer than the question which is the court's immediate concern. Witness, for example, the hesitant quality of the opinion of the Supreme Court in the recent case of Hansberry v. Lee, ${ }^{85}$ in surveying the application of res judicata to class suits.

Nevertheless, the notion that there is somehow a necessary link between res judicata and participation in class suits will not down so easily. Two remaining arguments must be met. First, res judicata might seem essential to any rational theory of the class suit. If the absentees are allowed to participate in the decree, it must be because their rights are before the court by virtue of the plaintiff's representation. Thus, if the plaintiff loses, since their rights are before the court, the decree is res judicata. And conversely, if the decree would not have been res judicata, the absentees' rights cannot be before the court so as to permit participation by the absentees. It has thus seemed to some courts utter nonsense to talk of a class suit in a case where the decree admittedly would not bind absentee members. In Linden Land Co. v. Milwaukee Electric Rail way \& Light Co., ${ }^{86}$ the Wisconsin Supreme Court acidly observed:

The theory of the action, where one properly sues for all, is that the result is conclusive on all who are similarly situated and whom the plaintiff rightfully represents; and such must be the theory, or else the plaintiff does not represent all, and the statement that he does so is not only false but absurd. ${ }^{87}$

This point involves the dubious assumption that the absentees cannot come in after the decision if prior to the decision they were not in some fashion before the court. It is true that if the decree is conclusive against the absentees, their rights must have been adjudicated. But it is not contended that the absentees are before the court prior to the decision; in fact, it is agreed that in many instances they clearly are not. It is simply urged that the absentees be permitted to come in, albeit for the first time ${ }^{88}$ after the decree, because this result is essential to the policy con-

$$
{ }^{85} 3 \text { II U.S. } 32 \text { (I940). } \quad{ }^{86} \text { ro7 Wis. } 493,83 \text { N.W. } 85 \text { I (I900). } \quad{ }_{87}^{8} \text { Tbid., at } 508 .
$$

88 Where the statute of limitations has run while the suit is pending, there may be some technical difficulty in allowing participation by the absentees, if their rights are said not to be before the court prior to the running of the statute. It would seem clear that none of the supposed policies behind the statute support barring of the absentees. The defendant is apprised of the nature of claims of each and of the probability that it will be enforced against him. It is not a "stale" claim, there is no loss of relevant evidence, and finally, little would be gained by having the absentees intervene at an earlier date in the proceedings. Participation might be based 
siderations we have repeatedly emphasized. If it is necessary to translate this point into conventional terms, it might be said that the plaintiff invites the absentees to "intervene" in his suit after the decree or that there is a summary judgment in their favor because of a most extreme instance of stare decisis.

The second and perhaps more fundamental reason is simply thatlegal technicalities aside-it is unfair to afford the absentees all the benefits of winning but to impose upon them none of the burdens of losing. This, it seems, just isn't cricket. But it should be apparent from what has been said that there is by no means complete symmetry between binding the defendant to a favorable decree and binding the absentee to an unfavorable decree. Clearly, the defendant has been afforded his day in court; he has had the opportunity to present his case fully in his own right, and he has lost. He has no more reason to relitigate the entire controversy against the absentee members than he has to do so against the immediate plaintiff. But it cannot be said that the absentee has had his day in court to a comparable degree. He or counsel of his own choosing did not prepare and present his case. The defendant cannot properly complain about the way in which he is treated; he can complain only that the absentees are not also subjected to the risk of losing the case. But to the extent that the risk of losing would be greater on them because they are merely represented, it is only fair that they are not equally subjected to that risk.

It is probably true that the unfairness argument also derives some plausibility from the not unpopular assimilation of litigation to gambling. The absentees are permitted, it might be contended, in effect to place their bets after the race is over. This probably does violate the better gambling etiquette, but that is not an altogether relevant consideration here; the absentees can, of course, bring entirely new suits and substantially take advantage of the same hindsight afforded by the plaintiff's decision and the disclosure of the defendant's case.

Finally, the defendant's argument, insofar as it has weight at all, tends to broaden the scope of res judicata rather than to narrow the scope of

on the theory that the absentees ratify the plaintiff's suit on their behalf and that by familiar agency principles the ratification relates back to the date of commencement of the class action. The leading agency case is Bolton Partners v. Lambert, 4I Ch. Div. 295 (I88g); cf. Norwich Union Fire Ins. Co. v. Paramount Famous Lasky Corp., 50 F. (2d) 747 (C.C.A. 9th I93 I). If the absentees are not to be permitted to intervene after the statute has run, the plaintiff should be allowed to solicit their intervention under court auspices prior to the running of the statute instead of awaiting the decree. Where there are extremely short statutory periods as under the securities acts, the point may assume substantial importance. 
participation, and there are indications in Hansberry v. Lee that res judicata may be extended in class suits. ${ }^{89}$ The question of whether res judicata should be broadened does not depend on how desirable participation is; but rather on how desirable res judicata is. The germane considerations are not whether a class suit is involved but rather such factors as the desirability of quieting claims against the defendant, notice, and the adequacy of the representation.90 It is an extraordinary thing to bar a man who has not had an actual day in court, and the policy of assuring to each a day in court certainly competes with whatever policy there is in favor of putting an end to litigation. The difficulties of reconciling these policies are undeniably real. ${ }^{91}$ But the solution of the simple question of participation after decree should not be compelled to await the ultimate resolution of the res judicata question, which is at once more difficult and less significant.

\section{VI}

It has been seen that the need for remedying group wrongs, both to afford relief and to deter the commission of group injuries, presents a major problem in the contemporary administration of justice. It has also been seen that the individuals making up the group are usually in no position to act for themselves because of their lack of knowledge and the disproportion between the expense of seeking redress and their individual stake in the controversy. It has been the purpose of this article to explore the utility of the class suit as a solution to the problem, and to show that

\footnotetext{
89 "Nor do we find it necessary for the decision of this case to say that, when the only circumstance defining the class is that the determination of the rights of its members turns upon a single issue of fact or law, a state could not constitutionally adopt a procedure whereby some of the members of the class could stand in judgment for all, provided that the procedure were so devised and applied as to insure that those present are of the same class as those absent and that the litigation is so conducted as to insure the full and fair consideration of the common issue." 3II U.S. 32, 43 (I940).

${ }^{90}$ It is significant that the exclusive concern of the court in Hansberry v. Lee was with the question of adequacy of representation, although it seems probable that the class was defined by nothing more than a common question. See 49 Yale L. J. II25 (I940). In cases where the action is prosecuted or defended by chosen representatives, such as association cases, there is much to be said for making the decree binding since the representation is at least prima facie adequate. Smith v. Swormstedt, 16 How. (U.S.) 288 (I853), was a case of this type. Such cases would seem not to differ from the ordinary suit by a corporation through its directors.

${ }^{9 x}$ A possible solution, if the defendant wants to quiet claims by making the suit res judicata, would be to place on him the burden of notifying all absentees and thus affording them an opportunity to intervene after the decree and to make objections. Rule $23(\mathrm{c})$ does provide for notice in case of dismissal, but this provision has been held not to apply to a dismissal on the merits. Hutchinson v. Fidelity Investment Ass'n, I06 F. (2d) 43I (C.C.A. 4th I939). In any event only the most arbitrary results will follow if the effect of judgment is predicated primarily on the jural relations between the members of the class. 49 Yale L.J. Ir25 (I940).
} 
the efficacy of the class suit depends upon holding open the decree in successful suits to permit all absentees upon notice and solicitation to come in and participate in the benefits of the litigation, and that such group participation is available under contemporary law. It remains by way of conclusion to make the comparison already suggested between the class suit by private litigants and action by an administrative commission as competing methods of affording group redress. It must be noted, of course, that the two methods of group redress are not as a practical matter in competition with each other, inasmuch as the administrative law alternative is largely non-existent at the moment. Nevertheless, such a comparison may serve a double purpose. First, the contrast between private and public methods of redress for past injuries highlights certain strengths and weaknesses of the private litigation technique, and second, such a comparison may suggest possible areas for the further development of administrative law.

The choice seems then to be between the public official whose job and responsibility it is to function as an expert representative for the injured group and the amateur volunteer representative who brings the class suit. Stated in these terms, the choice is not a difficult one. But the more basic choice is between lawyers on public pay-roll and lawyers in private practice, and this choice is by no means so simple. That the representative in the administrative law method of redressing civil wrongs is the public lawyer requires no elaboration, but the exact role of the private lawyer in class suit litigation invites further comment.

It is the lawyer and only the lawyer who can properly be rewarded for the semi-public activity in a class suit. The impact of fees on the class suit is thus of prime importance. By performing services at the request of some of the group, the lawyer can, if he is successful, entitle himself to a fee based on the total claims of all. The striking thing is that although the fees may be large and attractive, ${ }^{92}$ they are awarded only on a quantum meruit basis. Although the result of transforming a small case into a big one is extraordinary from the lawyer's standpoint, there is no mystery as to the principle upon which the big fee is awarded. Once it has been

92 For a stimulating table of fees in New York derivative suit cases see Hornstein, The Counsel Fee in Stockholder's Derivative Suits, 39 Col. L. Rev. 784, 8 I $_{4}$ (I939). Such fees more than hold their own against the best the SEC could compile in reorganization cases. SEC Report, Part I, at 2xI et seq. (I937). The fees in the Bell Telephone case (note 5 supra) approximated one million dollars; those in the Insull case (note 4 supra) approximated five hundred thousand dollars. It is perhaps true that the fees in some of these cases were excessive and that the courts may have sometimes given too much attention to the contingent nature of the litigation. But the significant thing is that even if the fees were to be severely pared they would remain very substantial by all-time standards for legal services. 
decided that the class suit can be brought and that all can have the benefits, it follows necessarily that the successful lawyer has performed services equally valuable to all members of the class. He is awarded a large fee because he has performed a large service, and were his compensation to be measured by and paid out of the claims of his original plaintiffclient alone, there would clearly be unjust enrichment of the remainder of the class. This principle has perhaps been most definitively stated in a recent decision of the United States Supreme Court in a case which, curiously enough, did not involve a class suit.93 The plaintiff's original suit established a result which, solely on the doctrine of stare decisis, became immediately available to several others who were similarly situated. In allowing the plaintiff's application for an award of fees from the group, Mr. Justice Frankfurter said:

.... In her main suit the petitioner neither avowed herself to be the representative of a class nor did she automatically establish a fund in which others could participate. But in view of the consequences of stare decisis, the petitioner by establishing her claim necessarily established the claims of fourteen other trusts pertaining to the same bonds.

That the party in a situation like the present neither purported to sue for a class nor formally established by litigation a fund available to the class, does not seem to be a differentiating factor..... Whether one professes to sue representatively or formally makes a fund available for others may, of course, be a relevant circumstance in making the fund liable for his costs in producing it. But when such a fund is for all practical purposes created for the benefit of others, the formalities of the litigationthe absence of an avowed class suit or the creation of a fund, as it were, through stare decisis rather than through a decree-hardly touch the power of equity in doing justice as between a party and the beneficiaries of his litigation. ....94

It is, of course, obvious that the same result follows a fortiori in a class suit case. ${ }^{95}$

93 Sprague v. Ticonic Nat'I Bank, 307 U.S. I6I (1939).

94 Tbid., at I66. Cf. the statement of Cardozo, J.: "The plaintiff rendered services of value which the corporation has appropriated without requital. The plastic remedy of an equitable lien is adequate in such a case. ...." Schoenherr v. Van Meter, 215 N.Y. 548,552 , I09 N.E. 625,626 (1915) (suit to impress lien by an attorney hired by director to recover misappropriated funds).

95 Even where no money or property is recovered in the suit, the unjust enrichment principle should apply wherever it is at all practicable. For example, where an invalid tax assessment has been enjoined prior to the collection of any taxes, it may be possible to condition the withholding of the assessment as to each taxpayer upon his paying his pro rata share of the fees and expenses to some appropriate official. In a rate-payer case where an excessive rate has been reduced for the future, but no fund has been built up pending court litigation through a temporary injunction against the reduced rate schedule, the utility might be permitted to collect the fee from the consumers by being empowered to charge the excessive rate temporarily and to ear-mark the excess for this purpose. In the Bell Telephone litigation (note 5 supra), the fee was collected out of a fund which had been created over a period of many years through a temporary injunction. 
It is thus seen that the class suit is a vehicle for paying lawyers handsomely to be champions of semi-public rights. It is this quality of the class suit which gives vitality to the volunteer method of representation and obviates the apathy and general disinclination of the ordinary layman to assert anyone's rights but his own. ${ }^{96}$ Because of the lawyer's incentive, the suit which might be brought for the original plaintiff alone is legitimately turned into a class suit for all. And more important, the suit which might not be brought at all because the demands on legal skill and time would be disproportionate to the original client's stake can, when turned into a class suit, be brought and handled in a manner commensurate with its magnitude. Thus, the class suit as a way of redressing group wrongs is a semi-public remedy administered by the lawyer in private practice-and the opposition between public and private methods of group redress is, as has been said, an opposition between the public and private lawyer.

The first objection to the private system that comes to mind is that the moving of the private system of redress into action is highly accidental and haphazard. The protection of the semi-public interest depends upon placing the case in the hands of the lawyer by the individual client. No matter how competent, informed, ${ }^{97}$ and eager the lawyer may be,

${ }^{96}$ Serious doubts have been expressed with increasing frequency as to the efficacy of the derivative suit, chiefly because of the reluctance of any individual shareholder to begin suit or to resist settlement. Dodd, The Modern Corporation, Private Property, and Recent Federal Legislation, 54 Harv. L. Rev. 9I7, 925 (I94I); Hornstein, Legal Controls for Intra-Corporate Abuse, 4I Col. L. Rev. 405, 425 et seq. (I94); Berlack, Stockholders' Suits: A Possible Substitute, 35 Mich. L. Rev. 597 (1937). The question of the exact effectiveness of the derivative suit is difficult to determine on a factual basis and has been left largely to conjecture. Undeniably, the action is not completely satisfactory, but it may be suggested that it provides a better remedy and sanction than most of its recent critics would indicate. Primarily they have refused to consider explicitly the impetus given to the suit by the lawyer's role; thus arguments based on shareholders' disinterest are not necessarily sound. Some of the objections to derivative suits, such as delay, expense, etc., are common to all litigation; and others are peculiar to the suit itself and arise from defects in substantive law such as the disqualification as original plaintiffs of shareholders who bought subsequent to the wrong, the application of the statute of limitation, the failure to assess against the corporation expenses of bona fide but unsuccessful suits, and finally, the over-liberal definitions of managerial misconduct as abuses of discretion. If the derivative suit is literally impotent, the only alternative is some type of public enforcement such as is suggested in the text. Somewhat similar suggestions have been made. Berlack, op. cit. supra; Pound, Visitorial Jurisdiction over Corporations in Equity, 49 Harv. L. Rev. 369 (1936). And in any event no one would suggest that individual suits by shareholders each on his own behalf would provide a better remedy.

97 The prime purpose of the disclosure contained in SEC releases and in statements, proxies, prospectuses, and other materials subject to SEC supervision is to inform the investor and the markets. Publicity and the Security Market: A Case Study, 7 Univ. Chi. L. Rev. 676 (r940). Nevertheless, there is a concomitant function of such disclosures-to inform the lawyer. Much of the material would seem accessible only to the expert reader. 
he cannot act until at least one layman approaches him with the case..$^{88}$ By way of contrast, those administering the public system may act of their own volition and furthermore may discover violations in the first instance through the exercise of investigatory powers and the use of offcial reports. But the contrast is not so complete as it may at first seem. It must be remembered that public bodies by and large do not act unless some sort of private complaint has been made. The layman asking the commission to assert his rights does not differ much from the client complaining to his lawyer.

The "personnel" which administers the private system is chosen in a haphazard fashion. The client selects not only his own lawyer but the lawyer for the others in the group. Thus, there is virtually no restriction on the selection of the representative; 99 any lawyer may on occasion bring a class suit. The administrative personnel, on the other hand, is selected by standards which are certainly more stringent than those for general admission to the bar. The legal staffs of certain federal bodies, such as the SEC, are genuinely excellent and perhaps excel those of any law firms in the country, for it is a familiar story that in recent years the young men have been going to Washington..$^{100}$ Further, these staffs,

$9^{8}$ Undoubtedly, the bar is not overscrupulous in observing this requirement. From one point of view the requirement of the initial client does seem anachronistic; the class is the real client and the situation does not readily adjust to orthodox notions of the lawyer-client relationship. For one thing the lawyer's stake in the litigation will frequently far exceed that of his initial client. Since the client in these cases functions primarily to put into motion the machinery of the semi-public remedy, the question naturally arises: why not permit the lawyer alone to bring a class suit without an initial client? Of course, such a result represents so drastic a deviation from contemporary professional thought, that even if it were permitted, it would probably be shunned by a very large majority of the bar. Further, the question may prove too much. It may well prove that the lawyer if he were to act without a client would be so unequivocally a public representative that there would be no point in not putting him directly on the public pay-roll. Query, whether the same might not be said of the lawyer who is permitted to sue when he has only some members of the class as his clients?

99 There are two minor controls: (a) any member of the class may intervene and in a clear case of inadequate representation will be admitted to the control of the suit. Rule 24 provides for intervention in three situations corresponding to these subdivisions of Rule 23, but only with respect to suits under $23(a)(x)$ is express attention given to inadequacy of representation; (b) inadequacy of representation may be a sufficient reason for holding a decree not res judicata. Hansberry v. Lee, 3 II U.S. 32 (I940). But it is doubtful whether this doctrine extends to anything other than collusion or clear adverse interest. Occasionally, a court will not in the first instance permit a plaintiff to proceed because he is deemed an inadequate representative. Pelelas v. Caterpillar Tractor Co., II3 F. (2d) 629 (C.C.A. $7^{\text {th }}$ I940). It might be noted that the raising of this issue indicates exemplary solicitude on the part of the defendant. Rule ${ }_{23}$ (c) could well be construed to require notice to the class prior to dismissal in situations like this to afford other members of the class an opportunity to continue the suit.

${ }^{\text {roo }}$ Frankfurter, The Young Men Go to Washington, Law and Politics: Occasional Papers of Felix Frankfurter-1913-38, at 238 (1939). 
by virtue of specialization, become expert in certain limited fields, and it is not at all clear but that the complexity of the situations which give rise to large scale group injuries demands the specialist's knowledge and touch. Undeniably, there have been striking instances in recent years of a distrust of the competency of private litigation to determine adequately questions of public importance, the most notable perhaps being the legislation permitting the United States to intervene in any case in which the constitutionality of a federal statute is challenged. ${ }^{\text {ror }}$

Further, due to its expert position the administrative body can view a law as a whole and have regard for a consistent, coherent, politic application of it. In the case of much new social legislation, the tempering of the enforcement of law by such discretion is of real importance. For example, the Wage and Hour Division, particularly in the first years of the law, found it wise to create good will for the law by settling close cases on the basis of the employer's affidavit to comply in the future. Where a law depends to so high a degree on the voluntary compliance of those subject to it, such judicious application of the law is an important matter of "public relations." No such restraint can be expected if the law is administered through private litigation; rather, the method will result in an insistence upon the harshest results and the most technical interpretations.

Perhaps the most serious objection to the private litigation system for redressing group wrongs is one which concerns not the competence or discretion of the private lawyer but rather what might euphemistically be called his sense of loyalty. The reorganization bar, like the reorganization committee, was not altogether satisfactory in discharging the semi-public responsibility thrust upon it by the reorganization process. ${ }^{\text {102 }}$ But the

${ }^{\text {rox }} 50$ Stat. 75I (1937), 28 U.S.C.A. $\$ 401$ (Supp. 1940). The activity of the SEC in reorganizations under Chapter $\mathrm{X}$ of the Chandler Act is further evidence. See Berger, Intervention by Public Agencies in Private Litigation in the Federal Courts, 5o Yale L. J. 65 (I94I), recommending that public bodies be permitted to intervene purely on the basis of the publicimportance of the question. Cf. Singer \& Sons v. Union Pacific R. Co., 6r S. Ct. 254 (I940), a suit by a private person to enjoin the construction of an alleged extension by the railroad, in which the Court held that the plaintiff had no standing to sue. Mr. Justice Frankfurter, concurring, stated: "... to allow any private interest to thresh out the complicated questions that arise .... as for instance, whether a proposed construction is an 'extension' or 'a spur' .... is to invite dislocation of the scheme which Congress has devised for the expert conduct of the litigation of such issues." Ibid, at 259-60. Compare, however, the dissenting opinion of Mr. Justice Stone: "Instead it [Congress] gave authority to bring the suit to private parties in interest, who because of the injury especially inflicted upon them through the adverse effect of the unlawful extension on the public, have a peculiar incentive to protect the public interest. ...." Ibid., at 264 .

Ios Regarding the lawyers' role in the organization of investigation committees, Mr. Justice Douglas once quietly observed: "Or if an organization did result it was too often effectu- 
same opportunities for abuse are not present in the ordinary class suit case. Only where there is question of compromising the suit is there any occasion for a problem. And here the controls which currently exist under the federal rule, namely, notice and court approval, are sufficient to regulate suits which reach the courts. ${ }^{103}$ The only remaining problem is that of the lawyer who settles before his case reaches the courts. Frequently he and his client may be handsomely paid, although most of their recovery is a reward for not bringing the class suit. While in strictly legal terms it is true that the rest of the class retains its right to sue, as a practical matter this type of settlement may seriously impair the opportunities of the rest of the class to acquire knowledge of the wrong and to assert their rights effectively..$^{\mathrm{T} 4}$ The public system is not subject to being diverted ${ }^{\mathrm{ro5}}$ in this fashion unless there is resort to out and out bribery. Not only would it be difficult to devise any controls for such settlements in the private case, but it is not at all clear that the lawyer's conduct violates any existing canons of legal ethics.

The case for the administrative agencies, however, is not without its difficulties. Some of these, of course, have been the subject of debate since the days of Adam Smith. It is, however, pertinent to observe that to impose upon public agencies the task of asserting civil sanctions on behalf of injured groups will require a substantial increase in size, personnel and expenditures. Consider, for example, the position of the SEC were it to take over the task of protecting shareholders by bringing derivative suits. Nor is the personnel picture for the public agency all sweetness and light. For many years the public lawyers who have staffed district attorney and corporation counsel offices and state commissions have frequently been primarily political appointees. Despite the great improvements in federal agencies in recent years, it is still true that there is no tradition of public service and little development of a true civil servant

ated by an incompetent and piratical group of the legal profession who as often as not did the security-holders even more disservice than would the old management or financial group." Douglas, op. cit. supra note 3 , at 567 .

${ }^{103}$ These provisions should prevent a settlement from running to the representatives individually once the suit has been started; this was the purpose of the draftsmen. 2 Moore, Federal Practice 2277 ( 1938 ).

${ }^{104}$ Such settlements should at least operate as affirmative concealment for the purpose of suspending the statute of limitations.

xos It is this converse of the "strike suit" problem that is the real cause for concern. The difficulty with group remedies is not that the procedure encourages the bringing of groundless claims to extort settlements, but that it is vulnerable to having the representative in meritorious cases bought out. See Hornstein, op. cit. supra note 95 , at 425 et seq. 
attitude in America. It is disquieting that so many of the young lawyers presently serving in the federal commissions regard their jobs as sort of super-apprenticeships for private practice.

Perhaps a serious difficulty with greatly expanding the scope of administrative action by adding the responsibility of civil litigation is the effect such an increase in function will have on the impartiality and balance an administrative body is supposed to assume. If the administrative body is to sue civilly, it must take sides and become an advocate. ${ }^{\text {ro6 }}$ Too much can be made of this point; taking sides is not always an evil, and in fact, in exercising their injunctive powers, administrative bodies at present are in something of the advocate's position. But it is instructive to note that a few years ago Mr. Justice Douglas, in discussing a proposal to reform railroad reorganization procedure by giving the ICC the function of formulating the plan, said:

Such agency, whether it will or no, must be in a position similar to that of a courtlooking after the interests of the public generally and deciding with impartiality between the interests of the various groups of stockholders and creditors. Otherwise it would be placed in a position of active and many-sided partisanship. ${ }^{\text {xo7 }}$

For the sake of clarity this comparison has been in terms of exclusive alternatives. The best solution, however, is to draw upon both systems of enforcement, permitting both to develop side by side to check and complement each other. That such an arrangement is workable and valuable has already been shown by the experience with co-enforcement of the provisions of the wage and hour law by the Wage and" Hour Division and by the private class suit. Certainly proposals to extend administrative law in this direction, particularly with respect to the SEC, ${ }^{\text {,08 }}$ merit serious consideration. On the other hand the power of law administration through the private lawyer should not be underestimated. The efficiency of the private lawyer when the blue chips are down-and they are down in a class suit case-can make the class suit an effective instrument in contemporary administration of justice. And in any event, not all the young men go to Washington.

${ }^{206}$ In view of the concerted effort being made to turn administrative agencies into nisi prius courts, to suggest that they turn plaintiffs in civil litigation may perhaps be somewhat unseasonable and call forth from the agencies themselves Voltaire's "Heaven protect me from my friends, I can take care of my enemies myself."

zor Douglas, op. cit. supra note 3 , at 583 .

${ }^{103}$ As previously noted, the Wage and Hour Division does not have the power to sue for back wages but has secured restitution indirectly; see note 12 supra. It frould seem desirable that the division be empowered to bring suits directly on behalf of the employees. 